\title{
Exploring aerosol-cloud interaction using VOCALS-REx aircraft measurements
}

\author{
Hailing $\mathrm{Jia}^{1,2}$, Xiaoyan $\mathrm{Ma}^{1,2}$, and Yangang $\mathrm{Liu}^{3}$ \\ ${ }^{1}$ Collaborative Innovation Center on Forecast and Evaluation of Meteorological Disasters, Nanjing University of Information \\ Science \& Technology, Nanjing 210044, China \\ ${ }^{2}$ Key Laboratory for Aerosol-Cloud-Precipitation of China Meteorological Administration, School of Atmospheric Physics, \\ Nanjing University of Information Science \& Technology, Nanjing 210044, China \\ ${ }^{3}$ Environmental and Climate Sciences Department, Brookhaven National Laboratory, Upton, \\ New York 11973-5000, USA
}

Correspondence: Xiaoyan Ma (xma@nuist.edu.cn)

Received: 3 July 2018 - Discussion started: 25 October 2018

Revised: 17 April 2019 - Accepted: 20 May 2019 - Published: 18 June 2019

\begin{abstract}
In situ aircraft measurements obtained during the VAMOS (Variability of the American Monsoons) Ocean-Cloud-Atmosphere-Land Study Regional Experiment (VOCALS-REx) field campaign are analyzed to study the aerosol-cloud interactions in the stratocumulus clouds over the southeastern Pacific Ocean (SEP), with a focus on three understudied topics (separation of aerosol effects from dynamic effects, dispersion effects, and turbulent entrainmentmixing processes). Our analysis suggests that an increase in aerosol concentration tends to simultaneously increase both cloud droplet number concentration $\left(N_{\mathrm{d}}\right)$ and relative dispersion $(\varepsilon)$, while an increase in vertical velocity $(w)$ often increases $N_{\mathrm{d}}$ but decreases $\varepsilon$. After constraining the differences of cloud dynamics, the positive correlation between $\varepsilon$ and $N_{\mathrm{d}}$ becomes stronger, implying that perturbations of $w$ could weaken the aerosol influence on $\varepsilon$ and hence result in an underestimation of dispersion effect. A comparative analysis of the difference of cloud microphysical properties between the entrainment and non-entrainment zones suggests that the entrainment-mixing mechanism is predominantly extremely inhomogeneous in the stratocumulus that capped by a sharp inversion, whereby the variation in liquid water content $(25 \%)$ is similar to that of $N_{\mathrm{d}}(29 \%)$ and the droplet size remains approximately constant. In entrainment zone, drier air entrained from the top induces fewer cloud droplets with respect to total in-cloud particles $(0.56 \pm 0.22)$ than the case in the non-entrainment zone $(0.73 \pm 0.13)$ by promoting cloud droplet evaporation. This study is helpful in
\end{abstract}

reducing uncertainties in dispersion effects and entrainment mixing for stratocumulus, and the results of this study may benefit cloud parameterizations in global climate models to more accurately assess aerosol indirect effects.

\section{Introduction}

Stratocumulus clouds play a key role in the radiative energy budget of the Earth by reflecting incoming shortwave radiation and thus cooling the planet surface and offsetting the warming by greenhouse gases (Hartmann et al., 1992). Stratocumulus clouds are susceptible to aerosols, i.e., the aerosol indirect effect (Twomey, 1974; Albrecht, 1989), which currently remain with large uncertainties (Lohmann and $\mathrm{Fe}$ ichter, 2005; Chen and Penner, 2005; Carslaw et al., 2013; McCoy et al., 2017).

Globally, marine stratocumulus clouds overlaying the southeastern Pacific Ocean (SEP) are the largest and most persistent clouds (Klein and Hartmann, 1993; Bretherton et al., 2004). Sources of anthropogenic aerosols from the Chilean and Peruvian coasts, in contrast with the relatively clean air masses from the Pacific Ocean, make the SEP an ideal region for exploring the interaction between aerosols and stratocumulus cloud-topped boundary layers. The cloud properties from satellite retrievals exhibit a gradient off the northern Chile shore. For example, the cloud droplet number concentration decreased from 160 to $40 \mathrm{~cm}^{-3}$ (George and 
Wood, 2010), and the cloud droplet effective radius increased from 8 to $14 \mu \mathrm{m}$ from the coast to approximately $1000 \mathrm{~km}$ offshore (Wood et al., 2007). This gradient is plausibly attributable to anthropogenic aerosols near the coast. Huneeus et al. (2006) found that during easterly wind events, sulfate increased by 1 order of magnitude over the SEP, which resulted in a 1.6-fold to 2-fold increase in cloud droplet number concentration. Based on observations from satellites and cruises, Wood et al. (2008) suggested that open cellular convection within an overcast stratocumulus is associated with reduced aerosol concentration and air masses not passing through the Chilean coast, which further confirms the impact of aerosols on stratocumulus over the SEP. However, it is difficult to establish the generality of previous studies based on satellite remote sensing due to the absence of in situ observations that provide vertical profiles of cloud and aerosol and detailed in-cloud processes.

The VAMOS (Variability of the American Monsoons) Ocean-Cloud-Atmosphere-Land Study Regional Experiment (VOCALS-REx), which includes multiple aircraft missions, ship, and land-based measurements, took place in the region extending from the near-coast of northern Chile and southern Peru to the remote ocean in the SEP during OctoberNovember 2008 (Wood et al., 2011). The data collected during this campaign were examined to investigate the properties of aerosols, clouds, and the marine boundary layer over the SEP. For instance, Bretherton et al. (2010) found that the boundary layer was shallow and fairly well-mixed near shore but deeper and decoupled offshore. Twohy et al. (2013) found that the clouds near the shore exhibited higher aerosol concentrations, greater droplet concentrations, smaller droplet sizes, and a smaller liquid water path (LWP), and suggested a combination of anthropogenic aerosols and physically thinner clouds near the shore. However, Zheng et al. (2010) found an increase in the LWP with cloud condensation nuclei $(\mathrm{CCN})$ concentrations under the similar meteorological conditions. Additionally, chemical components and sources of aerosols during the VOCALS-REx campaign have been discussed in several studies (Chand et al., 2010; Hawkins et al., 2010; Allen et al., 2011; Twohy et al., 2013; Lee et al., 2014).

Although these studies have improved our understanding of some aspects related to aerosol, cloud, and boundary layer properties over SEP, several important factors remain understudied or unexplored. First, the aerosol effect on clouds is often intertwined with the effects of other factors, especially meteorological conditions (Fan et al., 2009; Koren et al., 2010). Currently, the impact of aerosols on the shape of the cloud droplet size spectrum (i.e., dispersion effect) is reported to remain large uncertainty. The observed correlations between relative dispersion $(\varepsilon)$ and $N_{\mathrm{d}}$ can be positive, negative, or not evident (Table 1), which could be largely attributable to the coincidentally changing cloud dynamics. Thus, it is necessary to isolate the response of $\varepsilon$ to aerosol perturbations from meteorological effects, which, to our knowledge, has not received adequate attention in many previous studies. Second, applying different assumptions to the entrainment-mixing mechanism can have a significant impact on the cloud albedo (Grabowski, 2006; Chosson et al., 2007; Slawinska et al., 2008). Additionally, more recent studies suggested that entrainment mixing may be a possible physical interpretation for the observed anti-Twomey effect (Ma et al., 2018; Jia et al., 2019). However, it remains unclear whether the entrainment-mixing mechanism is predominantly homogeneous, inhomogeneous, or in between (Andrejczuk et al., 2009; Lehmann et al., 2009). By using cloud observations obtained from G-1 aircraft during VOCALSREx, Yum et al. (2015) found both homogeneous and inhomogeneous mixing in their analysis and attributed the mixing to the uncertainty in the methods they used. Uncertainty in the entrainment-mixing mechanism could lead to the inaccurate assessment of aerosol indirect effects. Thus, more attention should be paid to this topic.

Based on the useful information on the microphysical properties of aerosols and clouds provided by previous studies, in this study, we conduct additional explorations regarding aerosol-cloud interactions over the SEP by employing in situ aircraft data collected by the Center for Interdisciplinary Remotely Piloted Aircraft Studies (CIRPAS) Twin Otter aircraft during VOCALS-REx, which include the following: (a) investigating the controlling factors of cloud droplet formation (e.g., cloud dynamics and aerosols), (b) evaluating the dispersion effect under relatively constant cloud dynamical conditions, and (c) re-examining the entrainment-mixing mechanism by using a different approach to that of Yum et al. (2015).

\section{Data and method}

\subsection{Aircraft data}

The Twin Otter aircraft operated by the Center for Interdisciplinary Remotely Piloted Aircraft Studies (CIRPAS) was aimed to observe aerosol and cloud microphysics and turbulence near Point Alpha $\left(20^{\circ} \mathrm{S}, 72^{\circ} \mathrm{W}\right)$ off the coast of northern Chile from 16 October to 13 November 2008. A total of 19 flights were carried out, each of which conducting about $3 \mathrm{~h}$ of sampling at Point Alpha and including several soundings and horizontal legs near the ocean surface, below the cloud, near the cloud base, within the cloud, near the cloud top, and above the cloud (Fig. 1). Since all flight tracks are similar, only one track (18 October) is shown in Fig. 1. As cloud and aerosol probe measurements failed during the flight on 5 November and drizzle processes occurred on the flights on 1 and 2 November, only the observations from other 16 non-drizzling flights are included in this paper.

Both the aerosols below and above clouds and the interstitial aerosols in-cloud were obtained by the Passive Cavity Aerosol Spectrometer Probe (PCASP), which counted 
Table 1. Correlations between $\varepsilon$ and $N_{\mathrm{d}}\left(N_{\mathrm{a}}\right)$ from observation studies.

\begin{tabular}{|c|c|c|c|c|}
\hline Observations & Observation type & Location & $\begin{array}{l}\text { Data for correlation } \\
\text { analysis }\end{array}$ & Correlation \\
\hline Liu and Daum (2002) & Aircraft & Ocean and coast & Flight averaged & Positive \\
\hline Peng and Lohmann (2003) & Aircraft & Coast & Flight averaged & Positive \\
\hline Pawlowska et al. (2006) & Aircraft & Ocean & $\begin{array}{l}\text { In flight } \\
\text { Flight averaged }\end{array}$ & $\begin{array}{l}\text { Negative } \\
\text { Positive }\end{array}$ \\
\hline Zhao et al. (2006) & Aircraft & Land, ocean, and coast & In flight & $\begin{array}{l}\varepsilon \text { converges to a small } \\
\text { range of values with in- } \\
\text { creasing } N_{\mathrm{d}}\end{array}$ \\
\hline Lu et al. (2007) & Aircraft & Ocean & $\begin{array}{l}\text { In flight } \\
\text { Flight averaged }\end{array}$ & $\begin{array}{l}\text { Negative } \\
\text { None for } N_{\mathrm{d}} \text {; positive } \\
\text { for } N_{\mathrm{a}}\end{array}$ \\
\hline Lu et al. (2012) & Aircraft & Land & $\begin{array}{l}\text { In flight } \\
\text { Flight averaged }\end{array}$ & $\begin{array}{l}\text { Negative } \\
\text { Negative }\end{array}$ \\
\hline Hudson et al. (2012) & Aircraft & Ocean & Flight averaged & Negative \\
\hline Ma et al. (2010) & Aircraft & Land & Flight averaged & Negative \\
\hline Pandithurai et al. (2012) & Aircraft & Land & Flight averaged & Positive \\
\hline Anil Kumar et al. (2016) & Ground-based & Land & - & Positive \\
\hline
\end{tabular}

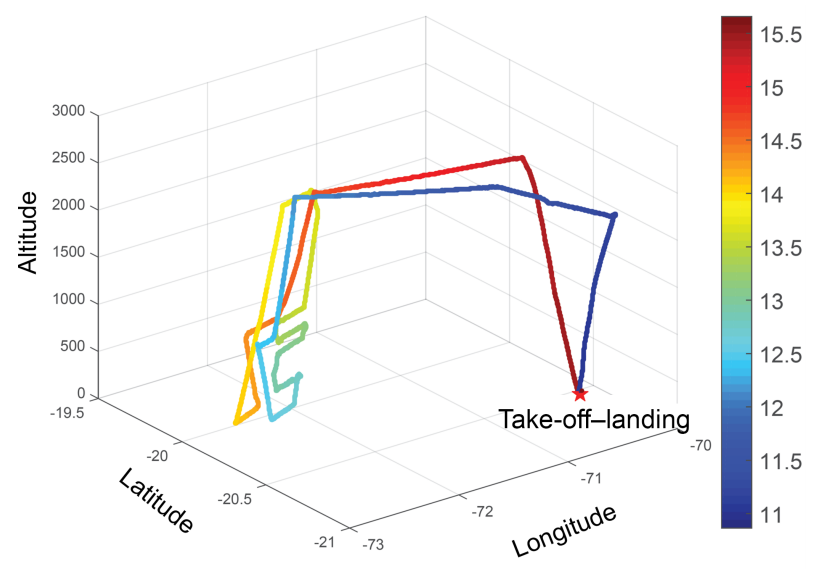

Figure 1. The flight track in 18 October; the colors represent flight time in hours (UTC).

and sized particles with a $0.1-2.0 \mu \mathrm{m}$ diameter with 20 bins (Zheng et al., 2011; Cai et al., 2013; Twohy et al., 2013). The CCN number concentration was observed by the CCN spectrometer at a supersaturation of $0.2 \%$ and $0.5 \%$. The cloud data include cloud droplet number concentration $\left(N_{\mathrm{d}}\right.$; size range: $2.07-40.2 \mu \mathrm{m}$ with 20 bins) from the Cloud, Aerosol and Precipitation probe (CAS); effective radius of cloud droplets $\left(R_{\mathrm{e}}\right)$; and liquid water content (LWC) from the PVM-100 probe (Gerber et al., 1994). All data sets used in this study are at a frequency of $1 \mathrm{~Hz}$. Zheng et al. (2011) pointed out that uncertainties of aerosols and clouds measured by these probes are within $15 \%$. More detailed information about the instruments and measurements aboard the CIRPAS Twin Otter aircraft during VOCALS-REx can be found in Zheng et al. (2010) and Wood et al. (2011).

\subsection{Data processing}

In this study, the data collected near the land during both take-off and landing are removed to ensure that only the measurements close to Point Alpha $\left(20^{\circ} \mathrm{S}, 72^{\circ} \mathrm{W}\right)$ are analyzed. Only the clouds with LWC $>0.05 \mathrm{~g} \mathrm{~m}^{-3}$ and $N_{\mathrm{d}}>15 \mathrm{~cm}^{-3}$ are selected for analysis. We averaged the $\mathrm{CCN}$ number concentrations during the legs within $200 \mathrm{~m}$ above the cloud top to obtain the average above-cloud $\mathrm{CCN}$ and within $200 \mathrm{~m}$ below the cloud base to obtain the mean sub-cloud CCN. During the study period, the $\mathrm{CCN}$ spectrometer constantly measured $\mathrm{CCN}$ at a supersaturation of $0.2 \%$, except on the first four flights, where it measured at a supersaturation of $0.5 \%$. In order to have a consistent comparison between all flights, we adopted the method by Zheng et al. (2011) to adjust the $\mathrm{CCN}$ concentration from supersaturation of $0.5 \%$ to $0.2 \%$ on the first four flights. The effective radius of the aerosol particle is calculated from the PCASP-measured aerosol size distributions based on the following equation:

$R_{\mathrm{a}}=\sum n_{i} r_{i}^{3} / \sum n_{i} r_{i}^{2}$,

where $n_{i}$ is the aerosol number concentration in the $i$ th bin of PCASP, and $r_{i}$ represents the arithmetic mean radius of the $i$ th bin.

To investigate the impact of the entrainment-mixing processes on cloud properties and aerosol-cloud interactions, we defined the entrainment zone and non-entrainment zone, respectively. Gerber et al. (2005) showed that, in the marine stratocumulus, entrainment occurs when LWC begins to decrease from the bottom of the cloud. In this paper, the entrainment and non-entrainment zone are thus defined as the regions within $20 \mathrm{~m}$ above and below the height of maximal LWC, respectively. Given that the two zones are both thin 
layers, there is little difference in the dynamical and thermosdynamical conditions. It is therefore assumed that the difference of cloud microphysical characteristics between the two zones is only caused by entrainment.

\section{Results}

\subsection{Vertical profiles of aerosol, cloud, and meteorological variables}

Figure 2 shows the vertical profiles of temperature (Fig. 2a), relative humidity (Fig. 2b), liquid water content (Fig. 2c), cloud droplet effective radius (Fig. 2d), cloud droplet number concentration (Fig. 2e), aerosol effective radius (Fig. 2f), and the ratio of $\mathrm{CCN}$ to condensation nuclei (Fig. 2g) during the 16 flights. Note that the vertical altitude is normalized by the inversion height $\left(z_{\mathrm{i}}\right)$, defined as the height of the maximum vertical gradient of liquid water potential temperature (Zheng et al., 2011). The normalization minimizes the effect of the variation in $z_{\mathrm{i}}$ between flights, allowing for better exploration of the average boundary layer (BL) structure during VOCALS-REx.

As shown in Fig. 2a, temperature $(T)$ decreased sharply with height within the BL, which is close to the dry adiabatic lapse rate. A strong inversion occurred at the top of the $\mathrm{BL}$, with an average temperature increase of approximately $10^{\circ} \mathrm{C}$. Due to the decrease in $T$ with height and the nearly constant water vapor mixing ratio within the strong mixing $\mathrm{BL}$, the relative humidity $(\mathrm{RH})$ increased rapidly with increasing height (Fig. 2b). $T$ and $\mathrm{RH}$ reached the minimum and maximum, respectively, when $z / z_{\mathrm{i}}$ was close to 0.9 . Near the top of the BL $\left(0.9<z / z_{\mathrm{i}}<1.0\right)$, the entrainment of the dry and warm air from the free atmosphere aloft resulted in a slight increase in $T$ and a slight decrease in RH. As $z / z_{\mathrm{i}}$ varied from 1 to $1.1, T$ increased from 11 to approximately $18^{\circ} \mathrm{C}$, and $\mathrm{RH}$ rapidly decreased to approximately $16 \%$ (Fig. 2a, b). The vertical profiles of $T$ and RH are overall consistent with the observations of other marine stratocumulus clouds (Martin et al., 1994; Keil and Haywood, 2003). For the cloud properties, an average of all profiles that are normalized by $z_{\mathrm{i}}$ only may be insufficient for indicating the vertical variation in clouds due to different cloud base heights of each profile. Thus, the average profiles are not shown in Fig. 2c, d, and e, and the vertical variation in cloud properties can easily be seen from the single profile. Figure $2 \mathrm{c}$ shows that the LWC first increased with height from the cloud base, reached the maximum at $z / z_{\mathrm{i}}=0.9$, and then decreased with further increasing height when $0.9<z / z_{\mathrm{i}}<1.0$. The profile of $R_{\mathrm{e}}$ is similar to that of LWC (Fig. 2d). The profile of $N_{\mathrm{d}}$ remains relatively constant, with a slight increase and decrease near the base and top, respectively (Fig. S1 in the Supplement), which is consistent with the results from other VOCALS-REx observations (Painemal and Zuidema, 2011). It is interesting to note that the effective radius of aerosol par- ticles $\left(R_{\mathrm{a}}\right)$ below cloud is larger than that above cloud, which is probably attributable to the differences in aerosol sources and aerosol properties (e.g., chemical composition; Fig. 2f). The profile of CCN/CN is similar to that of $R_{\mathrm{a}}$ (Fig. $2 \mathrm{~g}$ ), suggesting that aerosols with large sizes are more likely to become CCN (Dusek et al., 2006; Zhang et al., 2011). Larger $R_{\mathrm{a}}$ and $\mathrm{CCN} / \mathrm{CN}$ values are also found in polluted cases than in clean cases.

\subsection{Relationships between aerosol and cloud properties}

The relationships between aerosol and cloud properties are essential for understanding and evaluating aerosol-cloud interactions. Most studies based on satellite data have employed aerosol optical depth or the aerosol index as a proxy for CCN number concentration to investigate aerosol-cloud interactions (Koren et al., 2005, 2010; Su et al., 2010; Tang et al., 2014; Ma et al., 2014, 2018; Wang et al., 2014, 2015; Saponaro et al., 2017). However, not all aerosols in the vertical column are actually involved in cloud formation; thus, this assumption is questionable, especially when the cloud layer is decoupled from the aerosol layer. For example, a few studies have shown that aerosols have little effect on cloud properties when aerosol and cloud layers are clearly separated (Costantino and Bréon, 2010, 2013; Liu et al., 2017). To further investigate this issue, the $\mathrm{CCN}$ number concentrations both below cloud (sub-CCN) and above cloud (abv$\mathrm{CCN}$ ) are examined for their impacts on the cloud properties.

Figure 3 shows the relationships between sub-CCN and cloud properties during all 16 non-drizzling flights. The red dots denote the 10 flights with a typical well-mixed boundary layer (BL). These flights also shared similar meteorological conditions, such as inversion heights and the jump of potential temperature and total water mixing ratio across the inversion (Zheng et al., 2010), and thus can be used to isolate the response of cloud properties to aerosol perturbations. The blue dots represent the other cases in which the conditions except the typical well-mixed BL, such as strong wind shear within the BL, moist layers above clouds, a strong decoupled $\mathrm{BL}$, and so on, are involved (Table 2). For the cases with a typical well-mixed BL, both LWC (Fig. 3a) and $N_{\mathrm{d}}$ (Fig. 3b) exhibited positive correlations with sub-CCN, with correlation coefficients of 0.60 and 0.79 , respectively. It is worth highlighting that the similar increases in $N_{\mathrm{d}}$ and LWC led to $R_{\mathrm{e}}$ having no evident correlation with sub-CCN (Fig. 3c), as expected from the conventional first aerosol indirect effect whereby a constant LWC is assumed. For the other cases (blue dots), the sub-CCN impacts on the cloud properties were not evident due to the large differences in the meteorological conditions and the BL structure.

Compared to sub-cloud $\mathrm{CCN}$, the influence of abovecloud $\mathrm{CCN}$ on cloud properties is very weak, even for the cases with a typical well-mixed BL. The absolute values of the correlation coefficient between the abv-CCN and cloud properties are all less than 0.4 (not shown), and none of 

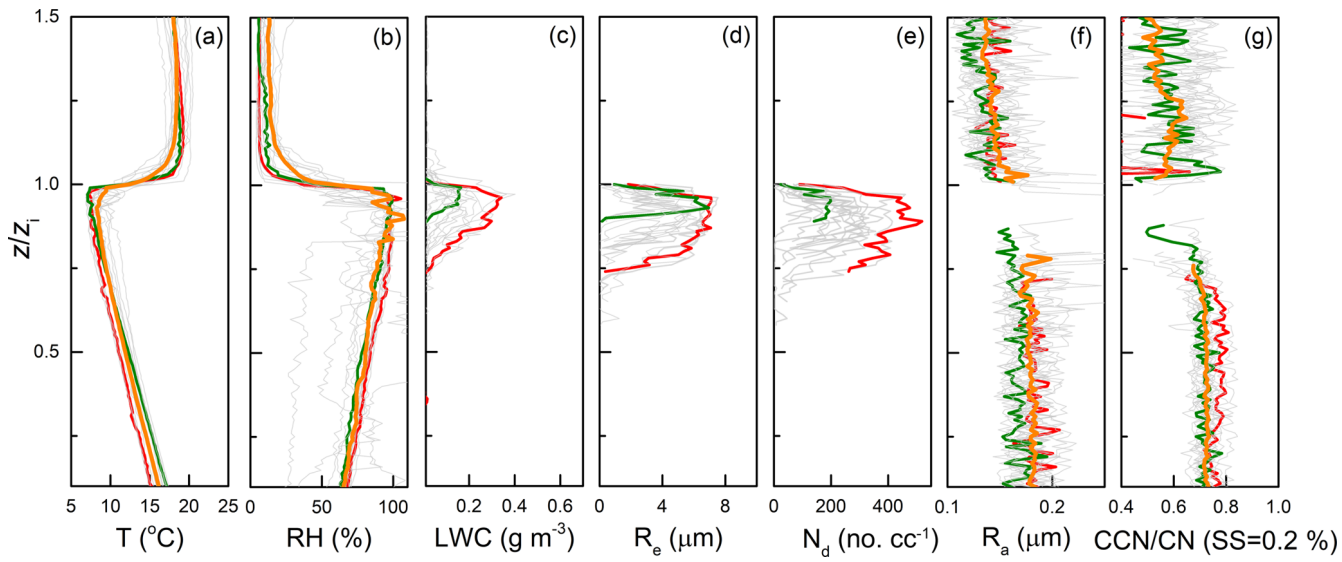

Figure 2. Vertical profiles scaled by the inversion height; (a) temperature $(\mathrm{K})$, (b) relative humidity $(\%),(\mathbf{c})$ liquid water content $\left(\mathrm{g} \mathrm{m}^{-3}\right)$, (d) cloud droplet effective radius $(\mu \mathrm{m})$, (e) cloud droplet number concentration $\left(\mathrm{cm}^{-3}\right)$, (f) aerosol effective radius $(\mu \mathrm{m})$, and $(\mathrm{g})$ the number concentration ratio of $\mathrm{CCN}$ to aerosols for all 16 non-drizzling flights. The gray lines show all individual flights, and the orange lines indicate the average profiles. The red and green lines represent the polluted (18 October) and clean (9 November) cases, respectively.
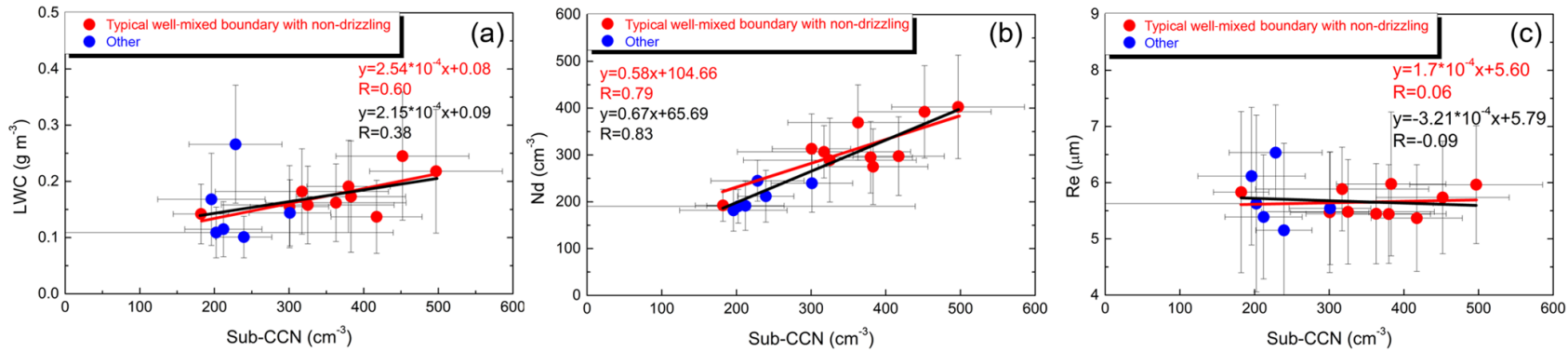

Figure 3. (a) $\mathrm{LWC}\left(\mathrm{g} \mathrm{cm}^{-3}\right)$, (b) $N_{\mathrm{d}}\left(\mathrm{cm}^{-3}\right)$, and (c) $R_{\mathrm{e}}(\mu \mathrm{m})$ as a function of sub-cloud CCN concentrations $(\mathrm{SS}=0.2 \%)$ for all 16 nondrizzling flights. The error bars through these symbols indicate the standard deviation. Red symbols are the cases with typical well-mixed BL discussed in Zheng et al. (2011), and blue symbols are for other cases. Red (black) texts are the correlation coefficient for typical well-mixed cases (all cases).

them passed the significance test $(\alpha=0.05)$. In this study, the above-cloud aerosol number concentration is very low $\left(129 \pm 60 \mathrm{~cm}^{-3}\right)$, and the inversion capping the cloud top is extremely strong, which weakens the aerosol mixing with cloud layer and hence the aerosol effects on cloud properties. Some previous studies based on aircraft observations for stratocumulus clouds also found that $N_{\mathrm{d}}$ exhibits a significantly positive correlation with sub-CCN but no correlation with abv-CCN (Martin et al., 1994; Hudson et al., 2010; Hegg et al., 2012).

Figure 4 contrasts the relationships of $N_{\mathrm{d}}$ (a) and $R_{\mathrm{e}}$ (b) as functions of LWC between the most polluted (19 October) and cleanest (9 November) cases with aerosol concentrations of $647 \pm 60$ and $268 \pm 35 \mathrm{~cm}^{-3}$, respectively. Also shown are the corresponding power-law fits. Although $N_{\mathrm{d}}$ and $R_{\mathrm{e}}$ both increased with first increasing LWC and then leveled off, there were significant detailed differences between the polluted and clean cases. The polluted case exhibits a steeper increase in $N_{\mathrm{d}}$ with increasing LWC than the clean case when LWC is small, whereas the opposite was true for $R_{\mathrm{e}}$. The low aerosol concentrations under the clean case inhibit the increase in $N_{\mathrm{d}}$ with LWC (Fig. 4a), which hence promotes the rapid increase in $R_{\mathrm{e}}$ with LWC (Fig. $4 \mathrm{~b}$ ). In contrast, there are enough particles that may potentially activated into cloud droplets under the polluted case; thus, $N_{\mathrm{d}}$ increases rapidly with LWC. As a certain amount of water is shared by large amount particles, the increase in $R_{\mathrm{e}}$ is limited. The result is consistent with the study in Beijing by Zhang et al. (2011), but the difference in cloud formations between the clean and polluted conditions is less evident, which is likely attributable to the much smaller difference in aerosol concentration in this study (approximately $400 \mathrm{~cm}^{-3}$ ) than that in Zhang et al. (2011; approximately $7000 \mathrm{~cm}^{-3}$ ).

\subsection{Cloud droplet formation and its controlling factors}

Sub-cloud CCN are considered to be a good proxy for aerosols entering a cloud. However, during the actual flight, it is difficult to simultaneously collect enough samples of sub-cloud CCN and cloud droplets, which may result in sta- 
Table 2. Flight information and parameters that represent the properties of entrainment during all 16 non-drizzling flights.

\begin{tabular}{|c|c|c|c|c|c|c|c|c|c|}
\hline Flight number & RF01 & RF02 & RF03 & RF04 & RF05 & RF06 & RF07 & RF08 & RF09 \\
\hline Date & 10.16 & 10.18 & 10.19 & 10.21 & 10.22 & 10.24 & 10.26 & 10.27 & 10.29 \\
\hline BL type & Typical & Typical & Typical & Typical & Typical & $\begin{array}{r}\text { Other } \\
\text { wind shear }\end{array}$ & Typical & Typical & $\begin{array}{r}\text { Other } \\
\text { decoupled }\end{array}$ \\
\hline$w$ ave $^{\mathrm{a}}$ & 0.09 & 0.08 & 0.11 & 0.08 & 0.08 & -0.06 & 0.06 & 0.08 & -0.13 \\
\hline$w \mathrm{SD}^{\mathrm{b}}$ & 0.42 & 0.55 & 0.58 & 0.51 & 0.51 & 0.30 & 0.56 & 0.41 & 0.61 \\
\hline$w$ skew $^{c}$ & -0.38 & -0.16 & -0.27 & -0.21 & -0.27 & 0.00 & -0.23 & 0.08 & -0.27 \\
\hline$P_{\text {LWC }}{ }^{\mathrm{d}}$ & 26 & 56 & 33 & 25 & 25 & 29 & -3 & 11 & 3 \\
\hline$P_{\mathrm{Nd}} \mathrm{e}^{\mathrm{e}}$ & 32 & 60 & 30 & 39 & 28 & 34 & 5 & 20 & 6 \\
\hline$P_{\mathrm{Re}}{ }^{\mathrm{f}}$ & -2 & -6 & 1 & -7 & -2 & 0 & -4 & -2 & -2 \\
\hline $\mathrm{AF}_{\text {ent }}{ }^{\mathrm{g}}$ & 0.77 & 0.52 & 0.58 & 0.85 & 0.49 & 0.52 & 0.51 & 0.76 & 0.81 \\
\hline $\mathrm{AF}_{\text {non-ent }}{ }^{\mathrm{h}}$ & 0.95 & 0.84 & 0.82 & 0.77 & 0.74 & 0.78 & 0.73 & 0.82 & 0.80 \\
\hline Flight number & RF10 & RF11 & RF12 & RF13 & RF14 & RF15 & RF16 & Total & \\
\hline Date & 10.30 & 11.04 & 11.08 & 11.09 & 11.10 & 11.12 & 11.13 & & \\
\hline BL type & $\begin{array}{r}\text { Other } \\
\text { wind shear }\end{array}$ & $\begin{array}{r}\text { Other wind shear, } \\
\text { decoupled }\end{array}$ & $\begin{array}{r}\text { Other } \\
\text { decoupled }\end{array}$ & Typical & Typical & Typical & $\begin{array}{r}\text { Other } \\
\text { wind shear }\end{array}$ & & \\
\hline$w$ ave & 0.02 & 0.07 & 0.02 & 0.08 & 0.09 & 0.09 & -0.02 & & \\
\hline$w \mathrm{SD}$ & 0.45 & 0.41 & 0.42 & 0.47 & 0.49 & 0.51 & 0.41 & & \\
\hline$w$ skew & -0.13 & -0.48 & -0.03 & -0.48 & -0.26 & -0.27 & -0.42 & & \\
\hline$P_{\text {LWC }}$ & 10 & 62 & 3 & 56 & 3 & -2 & 59 & 25 & \\
\hline$P_{\mathrm{Nd}}$ & 8 & 56 & 24 & 56 & -2 & 8 & 59 & 29 & \\
\hline$P_{\mathrm{Re}}$ & 0 & 4 & -8 & -2 & 3 & -3 & -1 & -2 & \\
\hline $\mathrm{AF}_{\text {ent }}$ & 0.73 & 0.66 & 0.84 & 0.28 & 0.70 & 0.67 & 0.56 & 0.64 & \\
\hline $\mathrm{AF}_{\text {non-ent }}$ & 0.82 & 0.97 & 0.77 & 0.50 & 0.79 & 0.60 & 0.64 & 0.77 & \\
\hline
\end{tabular}

a,b,c $w$ ave, $w$ SD, and $w$ skew are the average, standard deviation, and skewness of in-cloud vertical velocities, respectively. ${ }^{\text {d,e,f }} P_{\mathrm{LwC}}, P_{\mathrm{Nd}}$, and $P_{\mathrm{Re}}$ are the percentages of reduction in LWC, $N_{\mathrm{d}}$, and $R_{\mathrm{e}}$ within entrainment zone relative to non-entrainment zone (unit: \%). $\mathrm{g}, \mathrm{h} \mathrm{AF}_{\mathrm{ent}}$ and $\mathrm{AF}_{\text {non-ent }}$ are adiabatic fraction in entrainment zone and non-entrainment zone, respectively. Here, adiabatic fraction is defined as the ratio of the measured LWC to its adiabatic LWC that is calculated using pressure and temperature near cloud base.
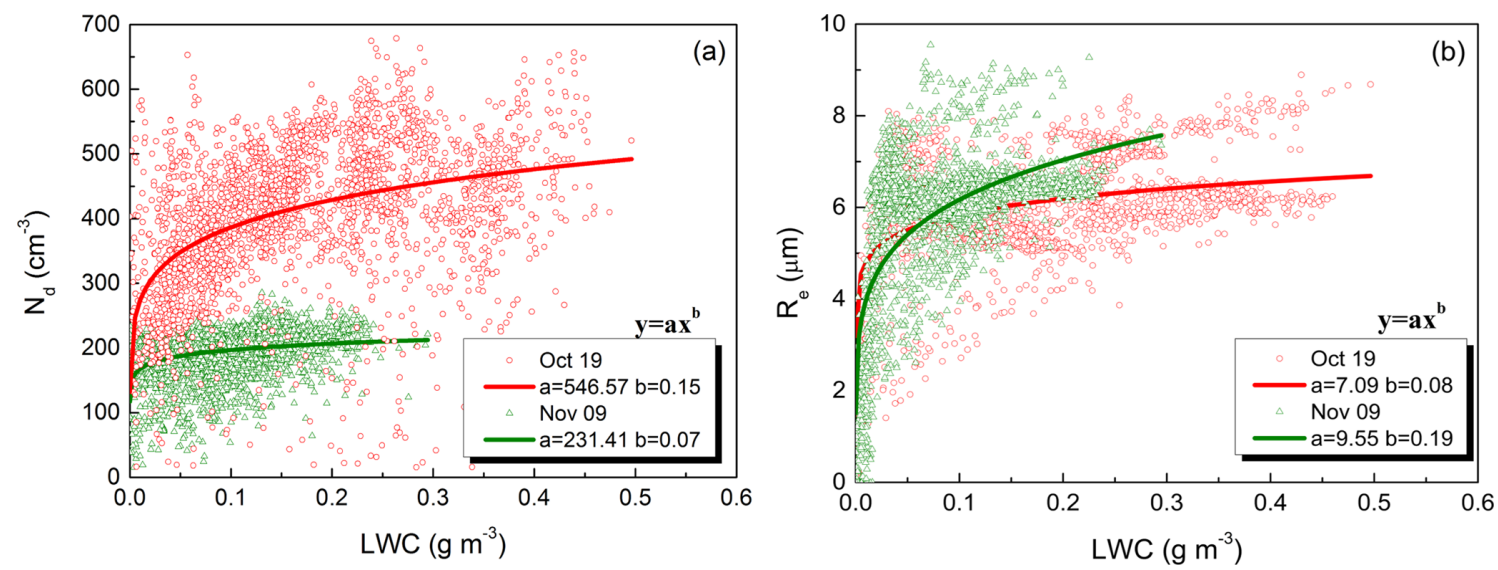

Figure 4. Correlations between (a) $N_{\mathrm{d}}\left(\mathrm{cm}^{-3}\right)$, (b) $R_{\mathrm{e}}(\mu \mathrm{m})$, and LWC $\left(\mathrm{g} \mathrm{m}^{-3}\right)$ for clean (green) and polluted (red) cases, respectively.

tistical analysis uncertainty. This limitation can be remedied by using the total particle concentration, which equals the aerosol concentration outside the clouds and the sum of the droplet concentration and interstitial aerosol concentration inside the clouds. Interstitial aerosols are particles observed inside clouds that either have never activated into cloud droplets or have been deactivated into aerosols after cloud droplet evaporation. Kleinman et al. (2012) pointed out that the number concentration of interstitial aerosols $\left(N_{\mathrm{i}}\right)$ can be obtained either directly from the observation of incloud aerosols or indirectly from a number balance between sub-cloud and in-cloud particles. In this study, the interstitial aerosol properties are derived from direct measurements in the cloud. By employing aircraft observations over both land and ocean, Gultepe and Isaac (1996) found that the difference in the number concentration between the total in-cloud 


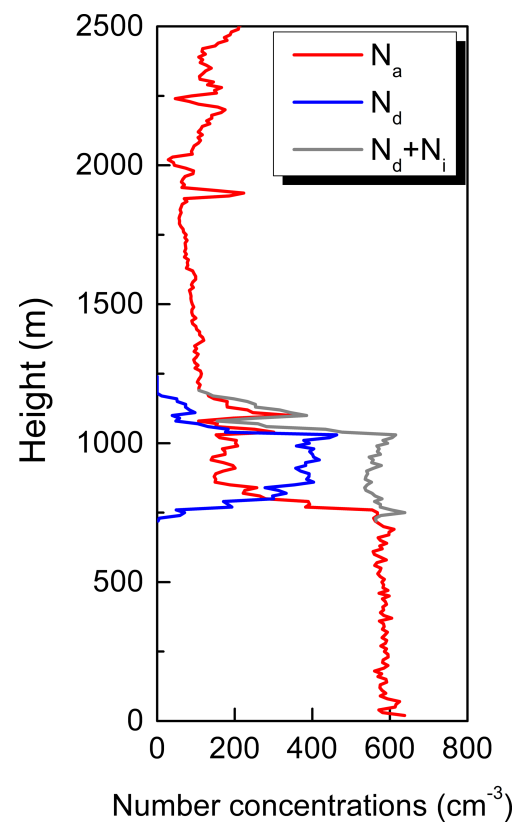

Figure 5. Vertical profiles of number concentrations of aerosols $\left(N_{\mathrm{a}}\right)$, cloud droplets $\left(N_{\mathrm{d}}\right)$, and total in-cloud particles $\left(N_{\mathrm{d}}+N_{\mathrm{i}}\right)$ during the flight on 18 October.

particles $\left(N_{\mathrm{d}}+N_{\mathrm{i}}\right)$ measured directly and sub-cloud aerosols is very small. Thus, the total in-cloud particles are assumed to characterize the overall level of in-cloud aerosol concentration before activation. Figure 5 shows an example of the 18 October flight to support this assumption. It is shown that the number concentrations of sub-cloud aerosols and total incloud particles are very close, with values of $583 \pm 55$ and $567 \pm 59 \mathrm{~cm}^{-3}$, respectively. Similar results are also found in the other flights. The average ratio of $N_{\mathrm{d}}+N_{\mathrm{i}}$ to the subcloud aerosol concentration during all flights is 0.94 , which is smaller than the value (1.29) found by Kleinman et al. (2012) based on G-1 aircraft measurements during VOCALS-REx. Therefore, the interstitial aerosol observations in this study are unlikely to be significantly interfered with by factors such as cloud droplet shatter and cloud droplet evaporation due to instrument heating, as discussed by Kleinman et al. (2012), which has the potential to create spurious extra aerosols in cloud.

The relations between $N_{\mathrm{d}}$ and $N_{\mathrm{d}}+N_{\mathrm{i}}$ during the 16 nondrizzling flights are shown in Fig. 6, where the color represents the in-cloud vertical velocity. All flights exhibited positive correlations between $N_{\mathrm{d}}$ and $N_{\mathrm{d}}+N_{\mathrm{i}}$, representing the aerosol-cloud interaction (IPCC, 2001, 2007, 2013; Hegg et al., 2012). In addition, the effect of dynamical conditions on cloud droplet formation is evident. As shown in Fig. 6, the data are close to the $1: 1$ line when the vertical velocity is relatively large; namely, the aerosols were almost entirely activated into cloud droplets. However, the data deviate from the $1: 1$ line when the vertical velocity is small or negative. For example, for all flights, the average ratio of $N_{\mathrm{d}}$ to $N_{\mathrm{d}}+N_{\mathrm{i}}$ with vertical velocity greater than $1 \mathrm{~m} \mathrm{~s}^{-1}$ is $0.84 \pm 0.12$, which is much larger than that with vertical velocity less than $-1 \mathrm{~m} \mathrm{~s}^{-1}(0.64 \pm 0.14)$. The regime-dependent behavior is likely due to the high supersaturation caused by the adiabatic uplift when the vertical velocity is large (Reutter et al., 2009; Chen et al., 2016).

In addition to the dynamical conditions, aerosol microphysical properties such as size distribution and chemical components can also significantly affect the activation process (Nenes et al., 2002; Lance et al., 2004; Ervens et al., 2005; Dusek et al., 2006; McFiggans et al., 2006; Zhang et al., 2011; Almeida et al., 2014; Leck and Svensson, 2015). Since part of the aerosol population was activated, it is difficult to obtain information about aerosol size before activation. According to the Köhler theory, larger aerosols have smaller critical supersaturations, and, thus, they activate preferentially, suggesting that the effective radius of interstitial aerosols $\left(R_{\mathrm{i}}\right)$ is smaller than that of the aerosols before activation. Li et al. (2011) compared the difference in size distribution between interstitial aerosols and aerosols that have been activated to cloud droplets and found that the peak diameter of the former $(0.45 \mu \mathrm{m})$ was much smaller than that of the latter $(0.8 \mu \mathrm{m})$. It can be thus inferred that the size of aerosols activated to cloud droplets, and thus the size of initial aerosols, would be larger with an increase in $R_{\mathrm{i}}$, though the quantitative relationship depends on in-cloud dynamics. Therefore, it is assumed that when compared with the data measured at different sampling locations during flight, the size of the interstitial aerosols can still represent the size of the aerosols before activation to some extent. As indicated in Fig. 7, the larger $R_{\mathrm{i}}$ is, the closer the data are to the $1: 1$ line, i.e., the higher the proportion of cloud droplets in total incloud particles $\left(N_{\mathrm{d}} /\left(N_{\mathrm{d}}+N_{\mathrm{i}}\right)\right)$. The averaged $N_{\mathrm{d}} /\left(N_{\mathrm{d}}+N_{\mathrm{i}}\right)$ for all flights is $0.76 \pm 0.13$ when $R_{\mathrm{i}}$ is larger than $0.5 \mu \mathrm{m}$ but only $0.64 \pm 0.23$ when $R_{\mathrm{i}}$ is less than $0.25 \mu \mathrm{m}$. It is because those aerosols with large sizes are more likely to be activated into cloud droplets. Additionally, as larger aerosol particles form into larger cloud droplets (Twohy et al., 1989, 2013) that are relatively difficult to evaporate, large particles can also inhibit cloud droplet evaporation to a certain extent.

\subsection{Dispersion effect}

In addition to modulating the cloud droplet number concentration, aerosols also affect the shape of cloud droplet size spectrum (referred to as the "dispersion effect") and thereby affect the cloud albedo (Liu and Daum, 2002). When the dispersion effect is taken into account, the estimated aerosol indirect forcing could be either reduced (Liu and Daum, 2002; Peng and Lohmann, 2003; Anil Kumar et al., 2016; Pandithurai et al., 2012) or enhanced (Ma et al., 2010), i.e., the dispersion effect could act to either offset or enhance the wellknown Twomey effect, which mainly depends on the sensitivity of the relative dispersion $(\varepsilon$; the ratio of the standard 


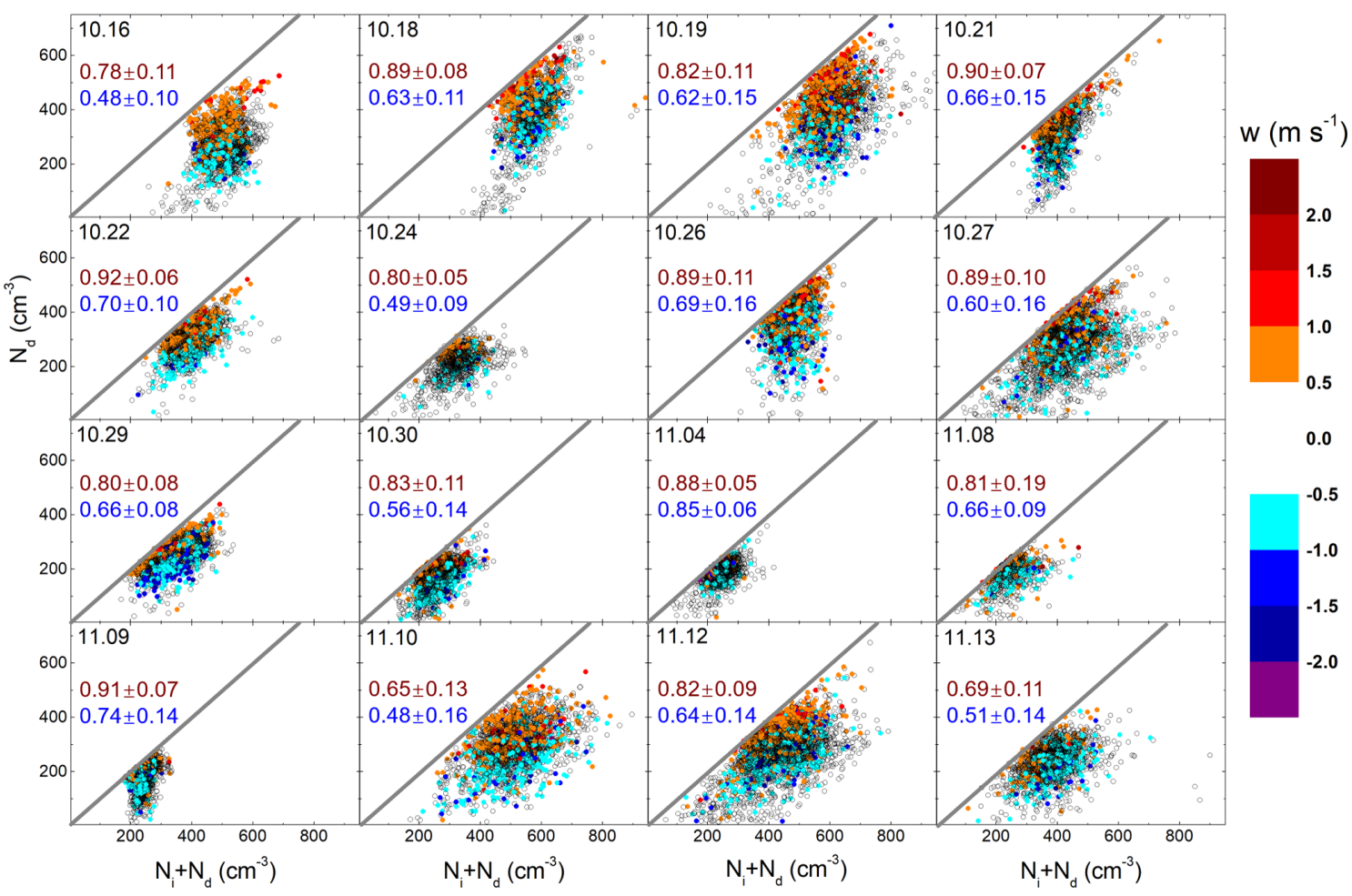

Figure 6. Relationships between $N_{\mathrm{d}}$ and $N_{\mathrm{i}}+N_{\mathrm{d}}$ during all 16 non-drizzling flights. The color represents in-cloud vertical velocities (m s ${ }^{-1}$ ), and gray line is $1: 1$ line. The mean and standard deviation of $N_{\mathrm{d}} /\left(N_{\mathrm{d}}+N_{\mathrm{i}}\right)$ for vertical velocity greater than $1 \mathrm{~m} \mathrm{~s}^{-1}$ (red) and less than $-1 \mathrm{~m} \mathrm{~s}^{-1}$ (blue) are shown.

deviation to the mean radius of the cloud droplet size distribution) to the aerosol number concentration $\left(N_{\mathrm{a}}\right)$. However, the dependence of $\varepsilon$ on $N_{\mathrm{a}}$ is much less studied and remains even more uncertain than that of $N_{\mathrm{d}}$. Table 1 summarizes the observed correlations between $\varepsilon$ and $N_{\mathrm{d}}$ (or $N_{\mathrm{a}}$ ), being positive, being negative, or having no obvious correlations. The different relationships are indicative of the fact that the effect of aerosol on $\varepsilon$ is often intertwined with the effects of other factors, especially cloud dynamical conditions (Pawlowska et al., 2006; Lu et al., 2012). In this section, the relationship between $\varepsilon$ and $N_{\mathrm{d}}$ based on in-flight and flight-averaged data is discussed to distinguish the influences of aerosol and cloud dynamics on $\varepsilon$.

Within an individual flight, the aerosol number concentration and chemical components can be assumed to be similar, providing an opportunity to focus on the effect of cloud dynamics to the extent possible. Here, we employ the vertical velocity $\left(w ; \mathrm{ms}^{-1}\right)$ as a proxy for cloud dynamical conditions. As shown in Fig. 8, the correlations between $\varepsilon$ and $N_{\mathrm{d}}$ based on in-flight data are significantly negative during all 16 non-drizzling flights, which is mainly modulated by $w$; i.e., a larger $w$ corresponds to a smaller $\varepsilon$ but a larger $N_{\mathrm{d}}$. High supersaturation leads to more cloud droplets to activate and grow to the same size (i.e., narrowing the droplet spectrum) when $w$ is relatively large, but a portion of the cloud droplets may evaporate into smaller sizes and even deactivate into in- terstitial aerosols when $w$ is small or even negative, resulting in a decrease in $N_{\mathrm{d}}$ and broadening of the droplet spectrum.

It is interesting to see from Table 1 that the correlations between $\varepsilon$ and $N_{\mathrm{d}}$ based on in-flight data are generally negative, while the correlations based on the flight-averaged data could be either positive, negative, or even uncorrelated. The latter uncertain relationships may result from variations in the strength of cloud dynamics between flights, which would disrupt or even cancel the real influence of aerosols on relative dispersion (Liu et al., 2006; Peng et al., 2007; Lu et al., 2012). However, many previous studies did not consider the difference in cloud dynamics between flights when correlating $\varepsilon$ and $N_{\mathrm{d}}$, which could result in some degree of overestimation or underestimation of dispersion effect. In this study, the data of all flights were sampled over the same location, i.e., Point Alpha, which can reduce the difference in dynamical conditions caused by variations in horizontal sampling locations. In addition, we also distinguish between the flights of a typical mixed BL and others to ensure relatively similar meteorological conditions (see Sect. 3.2). Figure 9 further shows the probability distribution function of $w$ with mean values and standard deviations for 16 non-drizzling flights. The related statistics are given in Table 2. Except for other cases (crosses; especially 24 October, 29 October, 8 November, and 13 November), the difference in the in-cloud dynamics between typical well-mixed BL flights is very small, 


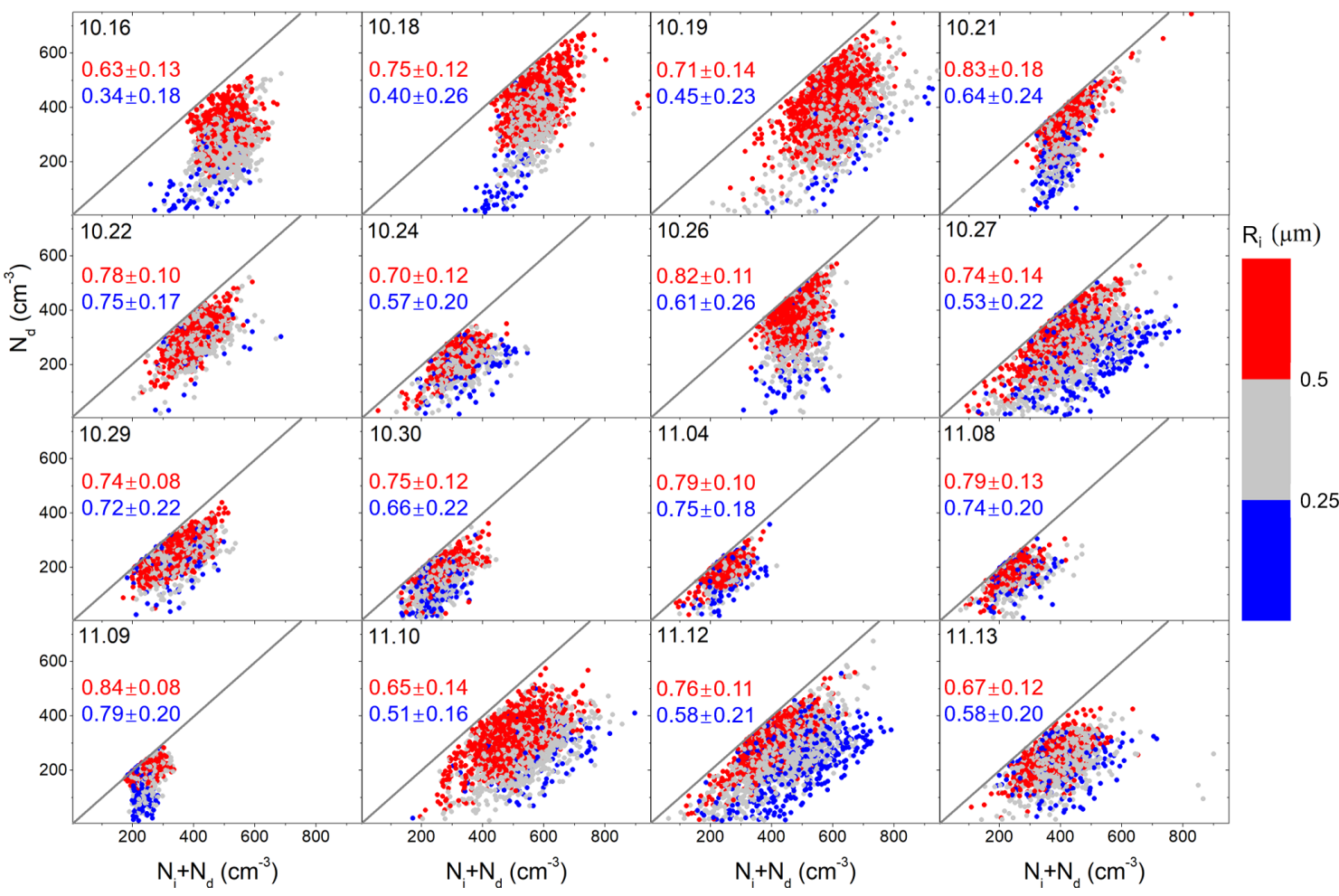

Figure 7. Same as Fig. 6, but the color represents the effective radius of interstitial aerosol $\left(R_{\mathrm{i}} ; \mu \mathrm{m}\right)$. The mean and standard deviation of $N_{\mathrm{d}} /\left(N_{\mathrm{d}}+N_{\mathrm{i}}\right)$ for $R_{\mathrm{i}}$ greater than $0.5 \mu \mathrm{m}$ (red) and less than $0.25 \mu \mathrm{m}$ (blue) are shown.

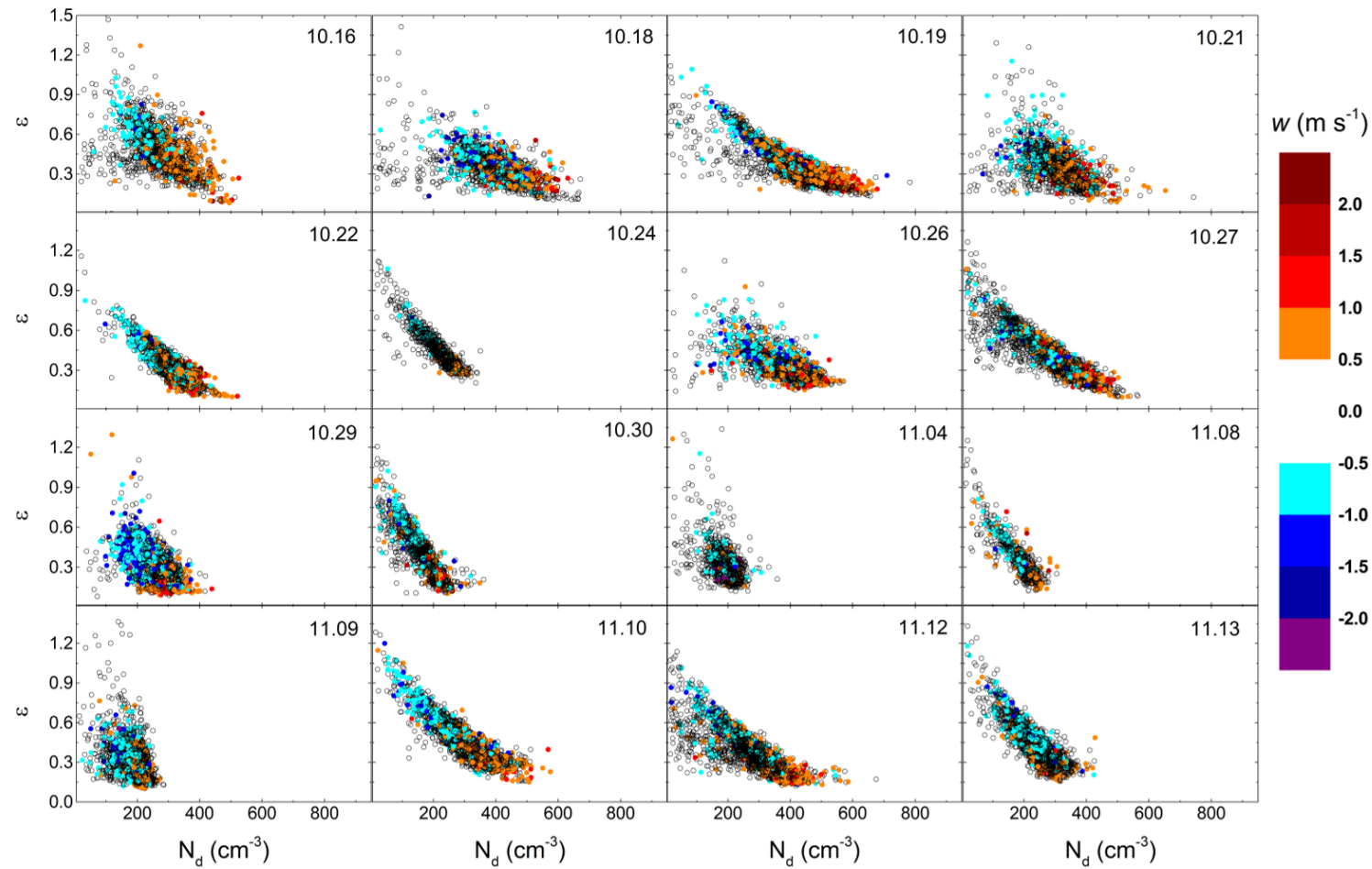

Figure 8. Relationships between relative dispersion $(\varepsilon)$ and $N_{\mathrm{d}}$ during all 16 non-drizzling flights, in which the color represents in-cloud vertical velocities $\left(\mathrm{m} \mathrm{s}^{-1}\right)$. 


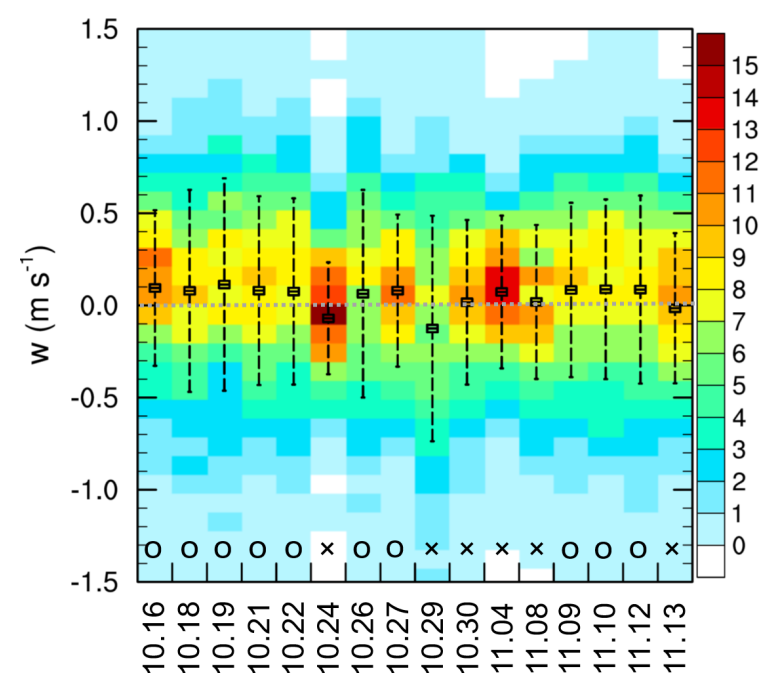

Figure 9. Probability distribution function (unit: \%) of vertical velocity $(w)$ for 16 non-drizzling flights. Black symbols are mean values of $w$, and error bars through these symbols indicate the standard deviation. Circles are the cases with typical well-mixed BL, and crosses represents the other cases.

which confirms the assumption of similar meteorological conditions. As indicated in Fig. 10a, $\varepsilon$ and $N_{\mathrm{d}}$ were positively correlated (correlation coefficient of 0.29 and slope of $1.9 \times 10^{-4}$ ) in the case of the typical well-mixed BL, indicating that increased aerosols concurrently increased $\varepsilon$ and $N_{\mathrm{d}}$. However, the correlation coefficient and slope decrease to 0.11 and $7.7 \times 10^{-5}$, respectively, in the all cases (i.e., $w$ is not constrained), implying that the influence of aerosols on the $\varepsilon-N_{\mathrm{d}}$ relationship tends to be weaker after intertwining with the effects of cloud dynamics. Although the perturbations of cloud dynamics have been eliminated as much as possible, $N_{\mathrm{d}}$ is still likely determined by both aerosol number concentrations and updraft velocity together. Therefore, a similar statistical analysis is also conducted for subcloud CCN. Similar positive correlations between $\varepsilon$ and subcloud CCN were found, with much-improved correlation coefficients (slopes). The correlation coefficients (slopes) were $0.67\left(3.1 \times 10^{-4}\right)$ and $0.31\left(2.1 \times 10^{-4}\right)$ for the cases with a typical well-mixed BL and all cases, respectively (Fig. 10b).

\subsection{Entrainment in stratocumulus}

Entrainment is a key process that occurs in the clouds and plays an important role in the formation and evolution of clouds and the change of droplet spectrum as well as the aerosol indirect effect (Chen et al., 2014, 2015; Andersen and Cermak, 2015). The nature of entrainment is related to the cloud type. Entrainment in cumulus is primarily lateral with strong dilution of the cloud, which induces LWC to decrease rapidly to approximately $20 \%$ of its adiabatic value (Warner, 1955). Entrainment in stratocumulus is mainly determined by the strength of the gradients in buoyancy and horizon- tal winds (Wang and Albrecht 1994; Gerber et al., 2005; de Roode and Wang 2007; Wood, 2012) and proceeds from the top and mostly affects a thin layer (Gerber et al., 2005), whose dilution effect is much weaker than that in cumulus (Warner, 1955, 1969a, b; Blyth et al., 1988; Gerber et al., 2008; Burnet and Brenguier, 2007; Haman et al., 2007). Aircraft observations of marine stratocumulus clouds showed that the vertical profile of LWC is essentially the same as the adiabatic profile; i.e., the cloud is almost adiabatic (Keil and Haywood, 2003). Furthermore, it remains unclear whether the subsequent entrainment-mixing mechanism is predominantly homogeneous, inhomogeneous, or in between (Andrejczuk et al., 2009; Lehmann et al., 2009). Some previous studies have shown that stratocumulus is generally dominated by the inhomogeneous mechanism (Pawlowska et al., 2000; Burnet and Brenguier, 2007; Haman et al., 2007; Lu et al., 2011; Yum et al., 2015). By employing a different vertical description in characterizing the region near the cloud top (Malinowski et al., 2013), Gerber et al. (2016) noted that both extremely inhomogeneous mixing and homogenous mixing play a role in unbroken stratocumulus, but the reduction in cloud droplet effective radius appears to be secondary in comparison to the dilution process that preserves the relative shape of the droplet spectrum.

To explore entrainment in stratocumulus during VOCALS-REx, we first compare the differences in cloud microphysics between the entrainment and nonentrainment zones near the cloud top. Here, the entrainment and non-entrainment zones are defined as the regions within $20 \mathrm{~m}$ above and below the height of the maximal LWC, respectively. As anticipated, the adiabatic fraction (AF; the ratio of the measured LWC to its adiabatic value) in the entrainment zone $\left(\mathrm{AF}_{\mathrm{ent}}\right)$ is generally lower than that in the non-entrainment zone $\left(\mathrm{AF}_{\text {non-ent }}\right)$, with mean values for all flights of 0.64 and 0.77 , respectively (Table 2), which further confirms the rationality of dividing the two zones. Compared with the non-entrainment zone, the peak radius of cloud droplets in the entrainment zone has few changes (Fig. 11), and the effective radius of cloud droplets $\left(R_{\mathrm{e}}\right)$ increases by only $2 \%$ (Table 2 ). However, $N_{\mathrm{d}}$ and LWC decrease significantly on average, by $29 \%$ and $25 \%$, respectively (Table 2), especially during the flights on 18 October, 4 November, 9 November, and 13 November, where $N_{\mathrm{d}}$ decreases by $60 \%, 56 \%, 56 \%$, and $59 \%$ and LWC decreases by $56 \%$, $62 \%, 56 \%$, and $59 \%$, respectively (Table 2). It is suggested that dry and warm air entrained from the cloud top dilutes $N_{\mathrm{d}}$ and LWC by similar amounts, while the size of droplets is relatively unaffected, which is thought of as being an extremely inhomogeneous entrainment-mixing process. Additionally, both $P_{\mathrm{LWC}}$ and $P_{\mathrm{Nd}}$ are negatively correlated with $\mathrm{AF}_{\text {ent }} / \mathrm{AF}_{\text {non-ent }}$, with correlation coefficients of -0.60 and -0.47 , respectively, indicating the dependence of the LWC and $N_{\mathrm{d}}$ changes on the adiabatic fraction changes (Fig. S2), where $P_{\mathrm{LWC}}$ and $P_{\mathrm{Nd}}$ are the reduction percentages 

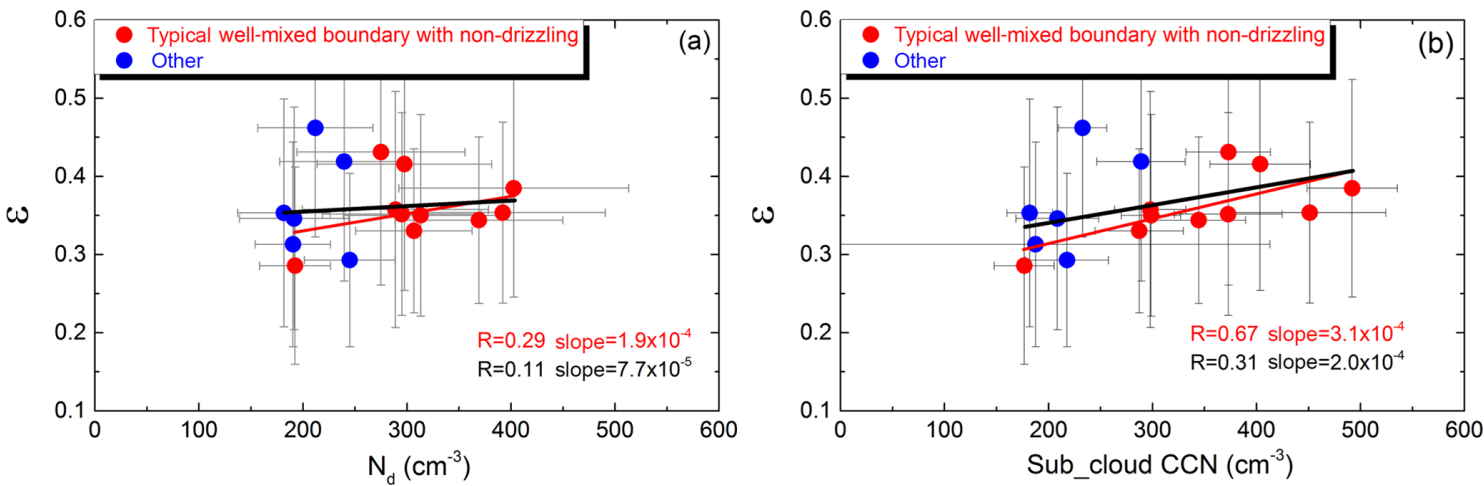

Figure 10. Relative dispersion $(\varepsilon)$ as a function of (a) $N_{\mathrm{d}}$ and (b) sub-cloud CCN concentrations (SS $=0.2 \%$ ) for all flights. The error bars through these symbols indicate the standard deviation. Red symbols are the cases with typical well-mixed BL, and blue symbols are for other cases. Red (black) texts are the correlation coefficient and slope for typical well-mixed cases (all cases).

in LWC and $N_{\mathrm{d}}$ within the entrainment zone relative to the non-entrainment zone.

The flight on 18 October with strong entrainment is chosen to investigate the difference between the entrainment and non-entrainment zones. As shown in Fig. 12b, dry and warm air entrained from the top reduced the $\mathrm{RH}$ in the entrainment zone by $9 \%$ on average and hence acted to accelerate cloud droplet evaporation. Consequently, $N_{\mathrm{d}} /\left(N_{\mathrm{d}}+N_{\mathrm{i}}\right)$ in the entrainment zone $(0.56 \pm 0.22)$ is much lower than that in non-entrainment zone $(0.73 \pm 0.13$; Fig. $12 \mathrm{c})$. Additionally, the relative dispersion in the entrainment zone is generally larger than that in the non-entrainment zone (Fig. 12d), implying that drier air entrained from the top could broaden the cloud droplet spectrum by promoting cloud droplet evaporation. Some previous observations also showed that $\varepsilon$ with a low $\mathrm{AF}$ tends to be larger than that with a high $\mathrm{AF}$ and attributed it to the effect of entrainment mixing (Pawlowska et al., 2006; Lu et al., 2009). It is noted that the occurrence frequency of $R_{\mathrm{i}}$ in the entrainment zone is significantly higher than that in the non-entrainment zone when $R_{\mathrm{i}}<0.38 \mu \mathrm{m}$, but the opposite is true when $R_{\mathrm{i}}>0.5 \mu \mathrm{m}$ (Fig. 12a). This result suggests that in addition to dry and warm air, small particles are also entrained into clouds from the top (Fig. 2f) and that large particles are detrained out of the clouds simultaneously. However, the inversion capping the typical stratocumulus is usually too strong to excite significant updrafts near the cloud top (Stevens, 2002; Wood, 2012; Malinowski et al., 2013). Ghate et al. (2010) found that vertical velocities near the top of stratocumulus tend towards zero overall, with only approximately $4 \%$ of updrafts being stronger than $0.5 \mathrm{~m} \mathrm{~s}^{-1}$. Therefore, although smaller aerosols are entrained into the entrainment zone, these aerosols seem unlikely to influence droplet formation. The effect of entrainment mixing on stratocumulus is mainly governed by the entrained dry air rather than small aerosols.

\section{Summary}

By using in situ aircraft data collected by the CIRPAS Twin Otter aircraft at Point Alpha during VOCALS-REx from 16 October to 13 November 2008, aerosol-cloud interactions are investigated with a focus on understudied factors, including separation of aerosol effects from dynamic effects, dispersion effects, and turbulent entrainment-mixing processes.

Vertical profiles of aerosol, cloud, and meteorological variables indicated that the BL was capped by a sharp inversion during 16 non-drizzling flights. Cloud properties, such as LWC and $N_{\mathrm{d}}$, are positively correlated with subcloud CCN number concentration, with correlation coefficients of 0.60 and 0.79 , respectively. No evident correlation was found between cloud properties and above-cloud CCN number concentrations. This is mainly due to the low aerosol number concentrations above cloud $\left(129 \pm 60 \mathrm{~cm}^{-3}\right)$ and the extremely strong inversion capping the cloud top, which inhibits the mixing of the above-cloud aerosols with the cloud layer. Therefore, the influence of the above-cloud $\mathrm{CCN}$ on cloud properties is weaker than the sub-cloud $\mathrm{CCN}$.

The results showed that both dynamical conditions and aerosol microphysical properties have significant effects on cloud droplet formation. In the case of large vertical velocity and aerosol size, the cloud droplet proportion of total in-cloud particles is relatively high (e.g., $0.84 \pm 0.12$ and $0.76 \pm 0.13$, respectively); i.e., cloud droplets form more easily. Although aerosol chemical components are also critical in cloud droplet formation (Nenes et al., 2002; Lance et al., 2004; Ervens et al., 2005; McFiggans et al., 2006; Wang et al., 2008; Almeida et al., 2014), this topic was not discussed in this study due to the unavailability of measurements.

The correlations between $\varepsilon$ and $N_{\mathrm{d}}$ based on the in-flight data, representing the $w$-induced correlation, are significantly negative, while the correlations derived from flightaveraged data (i.e., aerosol-induced correlation) are positive. This finding implies that an increase in aerosol concentration tends to concurrently increase $\varepsilon$ and $N_{\mathrm{d}}$, while an increase 


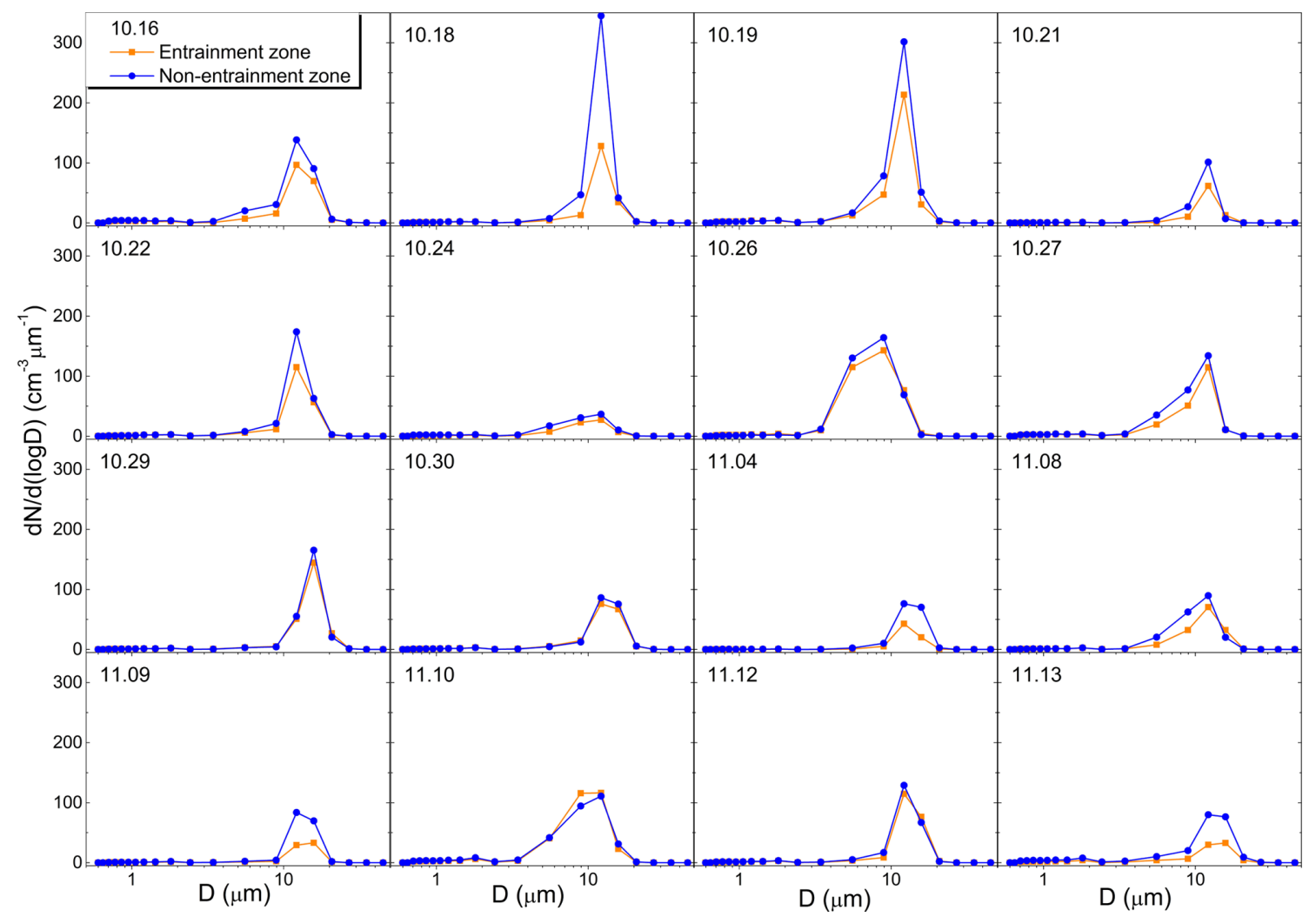

Figure 11. Number size distributions of cloud droplets in the entrainment (orange) and non-entrainment zones (blue) during all 16 nondrizzling flights.
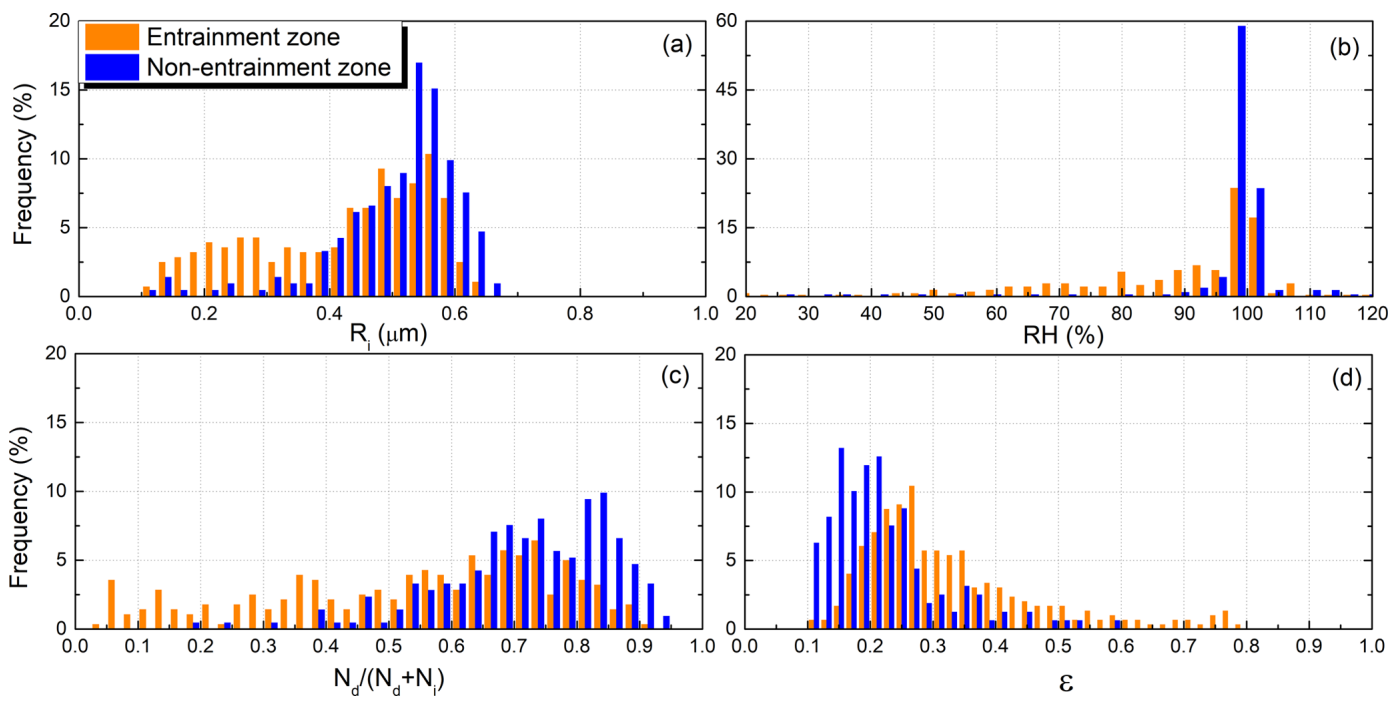

Figure 12. Probability density functions of (a) $R_{\mathrm{i}}(\mu \mathrm{m})$, (b) $\mathrm{RH}(\%)$, (c) $N_{\mathrm{d}} /\left(N_{\mathrm{d}}+N_{\mathrm{i}}\right)$, and (d) $\varepsilon$ in the entrainment (orange) and nonentrainment zones (blue) during the flight on 18 October.

in $w$ often increases $N_{\mathrm{d}}$ but decreases $\varepsilon$, which agrees with the theoretical analysis (Liu et al., 2006). After constraining the differences in cloud dynamics between flights, positive $\varepsilon-N_{\mathrm{d}}$ correlations become stronger, indicating that perturba- tions of $w$ could weaken the influence of aerosols on $\varepsilon$ and hence may result in an underestimation of aerosol dispersion effect. Thus, this finding highlights the necessity of isolating the relative dispersion response to aerosol perturbations from 
dynamic effects when investigating the aerosol dispersion effect and estimating aerosol indirect forcing.

Overall, the entrainment in stratocumulus is quite weak and close to being adiabatic in some cases. In this study, the difference in cloud microphysics between the entrainment and non-entrainment zones indicated that the entrainment in stratocumulus is mostly dominated by an extremely inhomogeneous entrainment-mixing mechanism. On average, the entrainment reduced $N_{\mathrm{d}}$ and LWC by $29 \%$ and $25 \%$, respectively, while having little effect on $R_{\mathrm{e}}$ (only increases by $1.8 \%$ ). During the flights on 18 October, 4 November, 9 November, and 13 November, the entrainment was relatively strong and diluted $N_{\mathrm{d}}$ and LWC by about $50 \%$. In the entrainment zone, the drier air entrained from the top resulted in a smaller $N_{\mathrm{d}} /\left(N_{\mathrm{d}}+N_{\mathrm{i}}\right)(0.56 \pm 0.22)$ than that in the non-entrainment zone $(0.73 \pm 0.13)$. This implies that entrainment may significantly influence cloud droplet formation and therefore influence the cloud properties near the top by promoting cloud droplet evaporation. Furthermore, we found that the relative dispersion in the entrainment zone is larger than that in the non-entrainment zone. In addition to the dry and warm air, aerosols with smaller sizes are also entrained into the entrainment zone, but these aerosols seem unlikely to influence cloud droplet formation due to the negligible droplet nucleation near the stratocumulus top. That is, the effect of entrainment mixing on stratocumulus is mainly determined by the entrained dry air instead of the aerosols with properties that are different from those near the cloud base. These results seem at odds with some studies on cumulus clouds. Slawinska et al. (2012) found that in a shallow cumulus, a significant part $(40 \%)$ of aerosols is activated above the cloud base (secondary activation), which is dominated by entrained aerosols. Using large-eddy simulations (LES), Hoffmann et al. (2015) suggested that sub-cloud aerosols and laterally entrained aerosols contribute to all activated aerosols inside the cloud by fractions of $70 \%$ and $30 \%$, respectively. Evidently, the topics of how and to what extent entrained aerosols with properties that are different from sub-cloud aerosols can affect the formation and evolution of clouds merit further exploration.

Data availability. The aircraft measurement data during VOCALSREx were obtained from the public FTP at http://data.eol.ucar.edu/ master_list/?project=VOCALS (last access: 30 May 2019). The navigation and state parameters are available from https://data. eol.ucar.edu/dataset/89.132 (Albrecht, 2011a). The cloud data are available from https://data.eol.ucar.edu/dataset/89.157 (Albrecht, 2011b). The CCN data are available from https://data.eol.ucar.edu/ dataset/89.156 (Albrecht, 2011c). The aerosol data are available from https://data.eol.ucar.edu/dataset/89.158 (Albrecht, 2011d).

Supplement. The supplement related to this article is available online at: https://doi.org/10.5194/acp-19-7955-2019-supplement.
Author contributions. HJ and XM designed the study and the statistical analysis. HJ processed the data and drafted the paper. XM and YL validated and debugged the results. All authors contributed to revising the paper.

Competing interests. The authors declare that they have no conflict of interest.

Acknowledgements. We are grateful for the dedicated efforts of several members of the support staff and scientists in making the observations from the CIRPAS Twin Otter during VOCALS-REx. We also thank Bruce Albrecht at the University of Miami for kindly providing the aerosol, cloud, and meteorological variable observations, which are the basis of this paper.

Financial support. This research has been supported by the National Natural Science Foundation of China grants (NSFC; grant no. 41475005), the National Key R\&D Program of China grants (grant no. 2016YFA0600404), the NSFC (grant no. 41675004), the Postgraduate Research \& Practice Innovation Program of Jiangsu Province (grant no. KYCX18_1005), and the funding of Jiangsu innovation \& entrepreneurship team. Yangang Liu is supported by the US Department of Energy's Atmospheric System Research (ASR) program.

Review statement. This paper was edited by Hugh Coe and reviewed by three anonymous referees.

\section{References}

Albrecht, B. A.: Aerosols, cloud microphysics, and fractional cloudiness, Science, 245, 1227-1230, 1989.

Albrecht, B.: University of Miami, CIRPAS Twin Otter Navigation and State Parameters, Version 1.0, UCAR/NCAR - Earth Observing Laboratory, available at: https://data.eol.ucar.edu/dataset/ 89.132 (last access: 30 May 2019), 2011a

Albrecht, B.: University of Miami, CIRPAS Twin Otter CAPS Probe Data, Version 1.0, UCAR/NCAR - Earth Observing Laboratory, available at: https://data.eol.ucar.edu/dataset/89.157 (last access: 30 May 2019), 2011b.

Albrecht, B.: University of Miami, CIRPAS Twin Otter CCN Data, Version 1.0, UCAR/NCAR - Earth Observing Laboratory, available at: https://data.eol.ucar.edu/dataset/89.156 (last access: 30 May 2019), 2011c.

Albrecht, B.: University of Miami, CIRPAS Twin Otter PCASP Data, Version 1.0, UCAR/NCAR - Earth Observing Laboratory, available at: https://data.eol.ucar.edu/dataset/89.158 (last access: 30 May 2019), 2011d.

Allen, G., Coe, H., Clarke, A., Bretherton, C., Wood, R., Abel, S. J., Barrett, P., Brown, P., George, R., Freitag, S., McNaughton, C., Howell, S., Shank, L., Kapustin, V., Brekhovskikh, V., Kleinman, L., Lee, Y.-N., Springston, S., Toniazzo, T., Krejci, R., Fochesatto, J., Shaw, G., Krecl, P., Brooks, B., McMeeking, G., 
Bower, K. N., Williams, P. I., Crosier, J., Crawford, I., Connolly, P., Allan, J. D., Covert, D., Bandy, A. R., Russell, L. M., Trembath, J., Bart, M., McQuaid, J. B., Wang, J., and Chand, D.: South East Pacific atmospheric composition and variability sampled along $20^{\circ} \mathrm{S}$ during VOCALS-REx, Atmos. Chem. Phys., 11, 5237-5262, https://doi.org/10.5194/acp-11-5237-2011, 2011.

Almeida, G. P., Brito, J., Morales, C. A., Andrade, M. F., and Artaxo, P.: Measured and modelled cloud condensation nuclei $(\mathrm{CCN})$ concentration in São Paulo, Brazil: the importance of aerosol size-resolved chemical composition on CCN concentration prediction, Atmos. Chem. Phys., 14, 7559-7572, https://doi.org/10.5194/acp-14-7559-2014, 2014.

Andersen, H. and Cermak, J.: How thermodynamic environments control stratocumulus microphysics and interactions with aerosols, Environ. Res. Lett., 10, 24004, https://doi.org/10.1088/1748-9326/10/2/024004, 2015.

Andrejczuk, M., Grabowski, W. W., Malinowski, S. P., and Smolarkiewicz, P. K.: Numerical simulation of cloud-clear air interfacial mixing: Homogeneous versus inhomogenous mixing, J. Atmos. Sci., 66, 2493-2500, 2009.

Anil Kumar, V., Pandithurai, G., Leena, P. P., Dani, K. K., Murugavel, P., Sonbawne, S. M., Patil, R. D., and Maheskumar, R. S.: Investigation of aerosol indirect effects on monsoon clouds using ground-based measurements over a high-altitude site in Western Ghats, Atmos. Chem. Phys., 16, 8423-8430, https://doi.org/10.5194/acp-16-8423-2016, 2016.

Blyth, A. M., Cooper, W. A., and Jensen, J. B.: A Study of the Source of Entrained Air in Montana Cumuli, J. Atmos. Sci., 45, 3944-3964, 1988.

Bretherton, C. S., Uttal, T., Fairall, C. W., Yuter, S. E., Weller, R. A., Baumgardner, D., Comstock, K., Wood, R., and Raga, G. B.: The Epic 2001 Stratocumulus Study, B. Am. Meteorol. Soc., 85, 967-977, 2004.

Bretherton, C. S., Wood, R., George, R. C., Leon, D., Allen, G., and Zheng, X.: Southeast Pacific stratocumulus clouds, precipitation and boundary layer structure sampled along $20^{\circ} \mathrm{S}$ during VOCALS-REx, Atmos. Chem. Phys., 10, 10639-10654, https://doi.org/10.5194/acp-10-10639-2010, 2010.

Burnet, F. and Brenguier, J. L.: Observational study of the entrainment-mixing process in warm convective clouds, J. Atmos. Sci., 64, 1995-2011, 2007.

Cai, Y., Snider, J. R., and Wechsler, P.: Calibration of the passive cavity aerosol spectrometer probe for airborne determination of the size distribution, Atmos. Meas. Tech., 6, 2349-2358, https://doi.org/10.5194/amt-6-2349-2013, 2013.

Carslaw, K. S., Lee, L. A., Reddington, C. L., Pringle, K. J., Rap, A., Forster, P. M., Mann, G. W., Spracklen, D. V., Woodhouse, M. T., Regayre, L. A., and Pierce, J. R.: Large contribution of natural aerosols to uncertainty in indirect forcing, Nature, 503, 67-71, 2013.

Chand, D., Hegg, D. A., Wood, R., Shaw, G. E., Wallace, D., and Covert, D. S.: Source attribution of climatically important aerosol properties measured at Paposo (Chile) during VOCALS, Atmos. Chem. Phys., 10, 10789-10801, https://doi.org/10.5194/acp-10-10789-2010, 2010.

Chen, J., Liu, Y., Zhang, M., and Peng, Y.: New understanding and quantification of the regime dependence of aerosol-cloud interaction for studying aerosol indirect effects, Geophys. Res. Lett., 43, 1780-1787, https://doi.org/10.1002/2016GL067683, 2016.
Chen, Y. and Penner, J. E.: Uncertainty analysis for estimates of the first indirect aerosol effect, Atmos. Chem. Phys., 5, 2935-2948, https://doi.org/10.5194/acp-5-2935-2005, 2005.

Chen, Y.-C., Christensen, M. W., Stephens, G. L., and Seinfeld, J. H.: Satellite-based estimate of global aerosol-cloud radiative forcing by marine warm clouds, Nat. Geosci., 7, 643-646, 2014

Chen, Y.-C., Christensen, M. W., Diner, D. J., and Garay, M. J.: Aerosol-cloud interactions in ship tracks using TerraMODIS/MISR, J. Geophys. Res.-Atmos., 120, 2819-2833, 2015.

Chosson, F., Brenguier, J.-L., and Schuller, L.: Entrainment-mixing and radiative transfer simulation in boundary layer clouds, J. Atmos. Sci., 64, 2670-2682, 2007.

Costantino, L. and Bréon, F.-M.: Analysis of aerosol-cloud interaction from multi-sensor satellite observations, Geophys. Res. Lett., 37, L11801, https://doi.org/10.1029/2009GL041828, 2010.

Costantino, L. and Bréon, F.-M.: Aerosol indirect effect on warm clouds over South-East Atlantic, from co-located MODIS and CALIPSO observations, Atmos. Chem. Phys., 13, 69-88, https://doi.org/10.5194/acp-13-69-2013, 2013.

de Roode, S. R. and Wang, Q.: Do stratocumulus clouds detrain? FIRE I data revisited, Bound.-Lay. Meteorol., 122, 479-491, https://doi.org/10.1007/s10546-006-9113-1, 2007.

Dusek, U., Frank, G. P., Hildebrandt, L., Curtius, J., Schneider, J., Walter, S., Chand, D., Drewnick, F., Hings, S., Jung, D., Borrmann, S., and Andreae, M. O.: Size matters more than chemistry for cloud-nucleating ability of aerosol particles, Science, 312, 1375-1378, 2006.

Ervens, B., Feingold, G., and Kreidenweis, S. M.: Influence of water-soluble organic carbon on cloud drop number concentration, J. Geophys. Res., 110, D18211, https://doi.org/10.1029/2004JD005634, 2005.

Fan, J., Yuan, T., Comstock, J. M., Ghan, S., Khain, A., Leung, L. R., Li, Z., Martins, J. V., and Ovchinnikov, M.: Dominant role by vertical wind shear in regulating aerosol effects on deep convective clouds, J. Geophys. Res., 114, D22206, https://doi.org/10.1029/2009JD012352, 2009.

George, R. C. and Wood, R.: Subseasonal variability of low cloud radiative properties over the southeast Pacific Ocean, Atmos. Chem. Phys., 10, 4047-4063, https://doi.org/10.5194/acp-104047-2010, 2010.

Gerber, H., Arends, B. G., and Ackerman, A. S.: A new microphysics sensor for aircraft use, Atmos. Res., 31, 235-252, 1994.

Gerber, H., Frick, G., Malinowski, S. P., Brenguier J.-L., and Burnet, F.: Holes and entrainment in stratocumulus, J. Atmos. Sci., 62, 443-459, 2005.

Gerber, H., Frick, G., Jensen, J. B., and Hudson, J. G.: Entrainment, mixing and microphysics in trade-wind cumulus, J. Meteorol. Soc. Jpn., 86A, 87-106, 2008.

Gerber, H., Malinowski, S. P., and Jonsson, H.: Evaporative and radiative cooling in POST stratocumulus, J. Atmos. Sci., 73, 38773884, https://doi.org/10.1175/Jas-D-16-0023.1, 2016.

Ghate, V. P., Albrecht, B. A., and Kollias, P.: Vertical velocity structure of nonprecipitating continental boundary layer stratocumulus clouds, J. Geophys. Res., 115, D13204, https://doi.org/10.1029/2009JD013091, 2010.

Grabowski, W. W.: Indirect impact of atmospheric aerosols in idealized simulations of convective-radfiative equilibrium, J. Climate, 19, 4664-4682, 2006. 
Gultepe, I. and Isaac, G.: The relationship between cloud droplet and aerosol number concentrations for climate models, Int. J. Climatol., 16, 941-946, https://doi.org/10.1002/(SICI)10970088(199608)16:8<941::AID-JOC57>3.0.CO;2-O, 1996.

Haman, K. E., Malinowski, S. P., Kurowski, M. J., Gerber, H., and Brenguier, J.-L.: Small scale mixing processes at the top of a marine stratocumulus - A case study, Q. J. Roy. Meteor. Soc., 133, 213-226, 2007.

Hartmann, D. L., Ockert-Bell, M. E., and Michelsen, M. L.: The effect of cloud type on Earth's energy balance: Global analysis, J. Climate, 5, 1281-1304, 1992.

Hawkins, L. N., Russell, L. M., Covert, D. S., Quinn, P. K., and Bates, T. S.: Carboxylic acids, sulfates, and organosulfates in processed continental organic aerosol over the southeast Pacific Ocean during VOCALS-Rex 2008, J. Geophys. Res., 115, D13201, https://doi.org/10.1029/2009JD013276, 2010.

Hegg, D. A., Covert, D. S., Jonsson, H. H., and Woods, R. K.: A simple relationship between cloud drop number concentration and precursor aerosol concentration for the regions of Earth's large marine stratocumulus decks, Atmos. Chem. Phys., 12, 1229-1238, https://doi.org/10.5194/acp-12-1229-2012, 2012.

Hoffmann, F., Raasch, S., and Noh, Y.: Entrainment of aerosols and their activation in a shallow cumulus cloud studied with a coupled LCM-LES approach, Atmos. Res., 156, 43-57, 2015.

Hudson, J. G., Noble, S., and Jha, V.: Stratus cloud supersaturations, Geophys. Res. Lett., 37, 21813, https://doi.org/10.1029/2010GL045197, 2010.

Hudson, J. G., Noble, S., and Jha, V.: Cloud droplet spectral width relationship to CCN spectra and vertical velocity, J. Geophys. Res., 117, D11211, https://doi.org/10.1029/2012JD017546, 2012.

Huneeus, N., Gallardo, L., and Rutllant, J. A.: Offshore transport episodes of anthropogenic sulfur in northern Chile: Potential impact on the stratocumulus cloud deck, Geophys. Res. Lett., 33, L19819, https://doi.org/10.1029/2006GL026921, 2006.

IPCC: Climate Change: The Scientific Basis: contributions of Working Group I to the Third Assessment Report of the IPCC, edited by: Houghton, J. T., Ding, Y., Griggs, D. J., Noguer, M., van der Linden, P. J., Dai, X., Maskell, K., and Johnson, C. A., Cambridge University Press, New York, 881 pp., 2001.

IPCC: Climate Change: The Physical Science Basis: contribution of Working Group 1 to the Fourth Assessment Report of the IPCC, edited by: Solomon, S., Qin, D., Manning, M., Chen, Z., Marquis, M., Averyt, K. B., Tignor, M., and Miller, H. L., Cambridge University Press, New York, 996 pp., 2007.

IPCC: Climate change: The Physical Science Basis: contribution of Working group I to the Fifth Assessment Report of the IPCC, edited by: Stocker, T. F., Dahe, Q., Plattner, G. K., Tignor, M., Allen, S. K., Boschung, J., Nauels, A., Xia, Y., Bex, V., Midgley, P. M., Cambridge University Press, Cambridge, 1535 pp., 2013.

Jia, H., Ma, X., Quaas, J., Yin, Y., and Qiu, T.: Is Positive Correlation between Cloud Droplet Effective Radius and Aerosol Index over Land Due to Retrieval Artifacts or Real Physical Processes?, Atmos. Chem. Phys. Discuss., https://doi.org/10.5194/acp-201947, in review, 2019.

Keil, A. and Haywood, J. M.: Solar radiative forcing by biomass burning aerosol particles during safari 2000: a case study based on measured aerosol and cloud properties, J. Geophys. Res., 108, D13, https://doi.org/10.1029/2002JD002315, 2003.
Klein, S. A. and Hartmann, D. L.: The Seasonal Cycle of Low Stratiform Clouds, J. Climate, 6, 1587-1606, 1993.

Kleinman, L. I., Daum, P. H., Lee, Y.-N., Lewis, E. R., Sedlacek III, A. J., Senum, G. I., Springston, S. R., Wang, J., Hubbe, J., Jayne, J., Min, Q., Yum, S. S., and Allen, G.: Aerosol concentration and size distribution measured below, in, and above cloud from the DOE G-1 during VOCALS-REx, Atmos. Chem. Phys., 12, $207-$ 223, https://doi.org/10.5194/acp-12-207-2012, 2012.

Koren, I., Kaufman, Y. J., Rosenfeld, D., Remer, L. A., and Rudich, Y.: Aerosol invigoration and restructuring of Atlantic convective clouds, Geophys. Res. Lett., 32, LI4828, https://doi.org/10.1029/2005GL023187, 2005.

Koren, I., Feingold, G., and Remer, L. A.: The invigoration of deep convective clouds over the Atlantic: aerosol effect, meteorology or retrieval artifact?, Atmos. Chem. Phys., 10, 8855-8872, https://doi.org/10.5194/acp-10-8855-2010, 2010.

Lance, S., Nenes, A., and Rissman, T. A.: Chemical and dynamical effects on cloud droplet number: Implications for estimates of the aerosol indirect effect, J. Geophys. Res., 109, D22208, https://doi.org/10.1029/2004JD004596, 2004.

Leck, C. and Svensson, E.: Importance of aerosol composition and mixing state for cloud droplet activation over the Arctic pack ice in summer, Atmos. Chem. Phys., 15, 2545-2568, https://doi.org/10.5194/acp-15-2545-2015, 2015.

Lee, Y.-N., Springston, S., Jayne, J., Wang, J., Hubbe, J., Senum, G., Kleinman, L., and Daum, P. H.: Chemical composition and sources of coastal marine aerosol particles during the 2008 VOCALS-REx campaign, Atmos. Chem. Phys., 14, 5057-5072, https://doi.org/10.5194/acp-14-5057-2014, 2014.

Lehmann, K., Siebert, H., and Shaw, R. A.: Homogeneous and Inhomogeneous Mixing in Cumulus Clouds: Dependence on Local Turbulence Structure, J. Atmos. Sci., 66, 3641-3659, 2009.

Li, W., Li, P., Sun, G., Zhou, S., Yuan, Q., and Wang, W.: Cloud residues and interstitial aerosols from non-precipitating clouds over an industrial and urban area in northern China, Atmos. Environ., 45, 2488-2495, 2011.

Liu, Y., Daum, P. H., and Yum, S. S.: Analytical expression for the relative dispersion of the cloud droplet size distribution, Geophys. Res. Lett., 33, L02810, https://doi.org/10.1029/2005GL024052, 2006.

Liu, Y., de Leeuw, G., Kerminen, V.-M., Zhang, J., Zhou, P., Nie, W., Qi, X., Hong, J., Wang, Y., Ding, A., Guo, H., Krüger, O., Kulmala, M., and Petäjä, T.: Analysis of aerosol effects on warm clouds over the Yangtze River Delta from multi-sensor satellite observations, Atmos. Chem. Phys., 17, 5623-5641, https://doi.org/10.5194/acp-17-5623-2017, 2017.

Liu, Y. G. and Daum, P. H.: Anthropogenic aerosols - Indirect warming effect from dispersion forcing, Nature, 419, 580-581, 2002.

Lohmann, U. and Feichter, J.: Global indirect aerosol effects: a review, Atmos. Chem. Phys., 5, 715-737, https://doi.org/10.5194/acp-5-715-2005, 2005.

Lu, C., Liu, Y., and Niu, S.: Examination of turbulent entrainmentmixing mechanisms using a combined approach, J. Geophys. Res., 116, D20207, https://doi.org/doi:10.1029/2011jd015944, 2011.

Lu, C., Liu, Y., Niu, S., and Vogelmann, A. M.: Observed impacts of vertical velocity on cloud microphysics and implications 
for aerosol indirect effects, Geophys. Res. Lett., 39, L21808, https://doi.org/10.1029/2012GL053599, 2012.

Lu, M.-L., Conant, W. C., Jonsson, H. H., Varutbangkul, V., Flagan, R. C., and Seinfeld, J. H.: The Marine Stratus/ Stratocumulus Experiment (MASE): Aerosol-cloud relationships in marine stratocumulus, J. Geophys. Res., 112, D10209, https://doi.org/10.1029/2006JD007985, 2007.

Lu, M.-L., Sorooshian, A., Jonsson, H. H., Feingold, G., Flagan, R. C., and Seinfeld, J. H.: Marine stratocumulus aerosol-cloud relationships in the MASE-II experiment: Precipitation susceptibility in eastern Pacific marine stratocumulus, J. Geophys. Res., 114, D24203, https://doi.org/10.1029/2009JD012774, 2009.

Ma, J., Chen, Y., Wang, W., Yan, P., Liu, H., Yang, S., Hu, Z., and Lelieveld, J.: Strong air pollution causes widespread haze-clouds over China, J. Geophys. Res., 115, D18204, https://doi.org/10.1029/2009jd013065, 2010.

Ma, X., Yu, F., and Quaas, J.: Reassessment of satellite-based estimate of aerosol climate forcing, J. Geophys. Res.-Atmos., 119, 10394-10409, 2014.

Ma, X., Jia, H., Yu, F., and Quaas, J.: Opposite aerosol index-cloud droplet effective radius correlations over major industrial regions and their adjacent oceans, Geophys. Res. Lett., 45, 5771-5778, 2018.

Malinowski, S. P., Gerber, H., Jen-La Plante, I., Kopec, M. K., Kumala, W., Nurowska, K., Chuang, P. Y., Khelif, D., and Haman, K. E.: Physics of Stratocumulus Top (POST): turbulent mixing across capping inversion, Atmos. Chem. Phys., 13, 1217112186, https://doi.org/10.5194/acp-13-12171-2013, 2013.

Martin, G. M., Johnson, D. W., and Spice, A.: The measurement and parameterization of effective radius of droplets in warm stratocumulus clouds, J. Atmos. Sci., 51, 1823-1842, 1994.

McCoy, D. T., Bender, F. M., Mohrmann, J. K. C., Hartmann, D. L., Wood, R., and Grosvenor, D. P.: The global aerosol-cloud first indirect effect estimated using MODIS, MERRA, and AeroCom, J. Geophys. Res.-Atmos., 122, 1779-1796, 2017.

McFiggans, G., Artaxo, P., Baltensperger, U., Coe, H., Facchini, M. C., Feingold, G., Fuzzi, S., Gysel, M., Laaksonen, A., Lohmann, U., Mentel, T. F., Murphy, D. M., O'Dowd, C. D., Snider, J. R., and Weingartner, E.: The effect of physical and chemical aerosol properties on warm cloud droplet activation, Atmos. Chem. Phys., 6, 2593-2649, https://doi.org/10.5194/acp-6-25932006, 2006.

Nenes, A., Charlson, R. J., Facchini, M. C., Kulmala, M., Laaksonen, A., and Seinfeld, J. H.: Can chemical effects on cloud droplet number rival the first indirect effect?, Geophys. Res. Lett., 29, 1848, https://doi.org/10.1029/2002GL015295, 2002.

Painemal, D. and Zuidema, P.: Assessment of MODIS cloud effective radius and optical thickness retrievals over the Southeast Pacific with VOCALS-REx in situ measurements, J. Geophys. Res., 116, D24206, https://doi.org/10.1029/2011jd016155, 2011.

Pandithurai, G., Dipu, S., Prabha, T. V., Maheskumar, R. S., Kulkarni, J. R., and Goswami, B. N.: Aerosol effect on droplet spectral dispersion in warm continental cumuli, J. Geophys. Res., 117, D16202, https://doi.org/10.1029/2011JD016532, 2012.

Pawlowska, H., Brenguier, J. L., and Burnet, F.: Microphysical properties of stratocumulus clouds, Atmos. Res., 55, 15-33, 2000.

Pawlowska, H., Grabowski, W. W., and Brenguier, J.L.: Observations of the width of cloud droplet spec- tra in stratocumulus, Geophys. Res. Lett., 33, L19810, https://doi.org/10.1029/2006GL026841, 2006.

Peng, Y. and Lohmann, U.: Sensitivity study of the spectral dispersion of the cloud droplet size distribution on the indirect aerosol effect, Geophys. Res. Lett., 30, 1507, https://doi.org/10.1029/2003GL017192, 2003.

Peng, Y., Lohmann, U., Leaitch, R., and Kulmala, M.: An investigation into the aerosol dispersion effect through the activation process in marine stratus clouds, J. Geophys. Res., 112, D11117, https://doi.org/10.1029/2006JD007401, 2007.

Reutter, P., Su, H., Trentmann, J., Simmel, M., Rose, D., Gunthe, S. S., Wernli, H., Andreae, M. O., and Pöschl, U.: Aerosol- and updraft-limited regimes of cloud droplet formation: influence of particle number, size and hygroscopicity on the activation of cloud condensation nuclei (CCN), Atmos. Chem. Phys., 9, 70677080, https://doi.org/10.5194/acp-9-7067-2009, 2009.

Saponaro, G., Kolmonen, P., Sogacheva, L., Rodriguez, E., Virtanen, T., and de Leeuw, G.: Estimates of the aerosol indirect effect over the Baltic Sea region derived from 12 years of MODIS observations, Atmos. Chem. Phys., 17, 3133-3143, https://doi.org/10.5194/acp-17-3133-2017, 2017.

Slawinska, J., Grabowski, W. W., Pawlowska, H., and Wyszogrodzki, A. A.: Optical properties of shallow convective clouds diagnosed from a bulk-microphysics large-eddy simulation, J. Climate, 21, 1639-1647, 2008.

Slawinska, J., Grabowski, W. W., Pawlowska, H., and Morrison, H.: Droplet activation and mixing in large-eddy simulation of a shallow cumulus field, J. Atmos. Sci., 69, 444-462, 2012.

Stevens, B.: Entrainment in stratocumulus-topped mixed layers, Q. J. Roy. Meteor. Soc., 128, 2663-2690, https://doi.org/10.1256/qj.01.202, 2002

Su, W., Loeb, N. G., Xu, K.-M., Schuster, G. L., and Eitzen, Z. A. : An estimate of aerosol indirect effect from satellite measurements with concurrent meteorological analysis, J. Geophys. Res., 115, D18219, https://doi.org/10.1029/2010JD013948, 2010.

Tang, J., Wang, P., Mickley, L. J., Xia, X., Liao, H., Yue, X., Sun, L., and $\mathrm{Xia}$, J.: Positive relationship between liquid cloud droplet effective radius and aerosol optical depth over Eastern China from satellite data, Atmos. Environ., 84, 244-253, 2014.

Twohy, C. H., Austin, P. H., and Charlson, R. J.: Chemical consequences of the initial diffusional growth of cloud droplets: a clean marine case, Tellus B, 41, 51-60, 1989.

Twohy, C. H., Anderson, J. R., Toohey, D. W., Andrejczuk, M., Adams, A., Lytle, M., George, R. C., Wood, R., Saide, P., Spak, S., Zuidema, P., and Leon, D.: Impacts of aerosol particles on the microphysical and radiative properties of stratocumulus clouds over the southeast Pacific Ocean, Atmos. Chem. Phys., 13, 25412562, https://doi.org/10.5194/acp-13-2541-2013, 2013.

Twomey, S.: Pollution and Planetary Albedo, Atmos. Environ., 8, 1251-1256, 1974.

Wang, F., Guo, J., Wu, Y., Zhang, X., Deng, M., Li, X., Zhang, J., and Zhao, J.: Satellite observed aerosol-induced variability in warm cloud properties under different meteorological conditions over eastern China, Atmos. Environ., 84, 122-132, 2014.

Wang, F., Guo, J., Zhang, J., Huang, J., Min, M., Chen, T., Liu, H., Deng, M., and Li, X.: Multi-sensor quantification of aerosolinduced variability in warm clouds over eastern China, Atmos. Environ., 113, 1-9, 2015. 
Wang, Q. and Albrecht, B. A.: Observations of cloud-top entrainment in marine stratocumulus clouds, J. Atmos. Sci., 51, 15301547, 1994.

Warner, J.: The water content of cumuliform cloud, Tellus, 7, 449457, 1955

Warner, J.: The Microstructure of Cumulus Cloud. Part I. General Features of the Droplet Spectrum, J. Atmos. Sci., 26, 1049-1059, 1969a.

Warner, J.: The microstructure of cumulus clouds. Part II. The effect on droplet size distribution of cloud nucleus spectrum and updraft velocity, J. Atmos. Sci., 26, 1272-1282, 1969b.

Wood, R.: Stratocumulus clouds, Mon. Weather Rev., 140, 23732423, https://doi.org/10.1175/MWR-D-11-00121.1, 2012.

Wood, R., Bretherton, C., Huebert, B., Mechoso, C. R., and Weller, R.: VOCALS-SouthEast Pacific Regional Experiment (REx) Scientific Program Overview, available at: http://www.eol.ucar.edu/ projects/vocals/documentation/vocalsoverview.pdf (last access: January 2011), June 2007.

Wood, R., Comstock, K. K., Bretherton, C. S., Cornish, C., Tomlinson, J., Collins, D. R., and Fairall, C.: Open cellular structure in marine stratocumulus sheets, J. Geophys. Res., 113, D12207, https://doi.org/10.1029/2007JD009371, 2008.

Wood, R., Mechoso, C. R., Bretherton, C. S., Weller, R. A., Huebert, B., Straneo, F., Albrecht, B. A., Coe, H., Allen, G., Vaughan, G., Daum, P., Fairall, C., Chand, D., Gallardo Klenner, L., Garreaud, R., Grados, C., Covert, D. S., Bates, T. S., Krejci, R., Russell, L. M., de Szoeke, S., Brewer, A., Yuter, S. E., Springston, S. R., Chaigneau, A., Toniazzo, T., Minnis, P., Palikonda, R., Abel, S. J., Brown, W. O. J., Williams, S., Fochesatto, J., Brioude, J., and Bower, K. N.: The VAMOS Ocean-Cloud-AtmosphereLand Study Regional Experiment (VOCALS-REx): goals, platforms, and field operations, Atmos. Chem. Phys., 11, 627-654, https://doi.org/10.5194/acp-11-627-2011, 2011.
Yum, S. S., Wang, J., Liu, Y., Senum, G., Springston, S., McGraw, R., and Yeom, J. M.: Cloud microphysical relationships and their implication on entrainment and mixing mechanism for the stratocumulus clouds measured during the VOCALS project, J. Geophys. Res.-Atmos., 120, 5047-5069, 2015.

Zhang, Q., Quan, J., Tie, X., Huang, M., and Ma, X.: Impact Aerosol Particles on Cloud Formation: Aircraft Measurements in Beijing, China, Atmos. Environ., 45, 665-672, 2011.

Zhao, C., Tie, X., Brasseur, G., Noone, K. J., Nakajima, T., Zhang, Q., Zhang, R., Huang, M., Duan, Y., Li, G., and Ishizaka, Y.: Aircraft measurements of cloud droplet spectral dispersion and implications for indirect aerosol radiative forcing, Geophys. Res. Lett., 33, L16809, https://doi.org/10.1029/2006g1026653, 2006.

Zheng, X., Albrecht, B. A., Minnis, P., Ayers, K., and Jonson, H. H.: Observed aerosol and liquid water path relationships in marine stratocumulus, Geophys. Res. Lett., 37, L17803, https://doi.org/10.1029/2010GL044095, 2010.

Zheng, X., Albrecht, B., Jonsson, H. H., Khelif, D., Feingold, G., Minnis, P., Ayers, K., Chuang, P., Donaher, S., Rossiter, D., Ghate, V., Ruiz-Plancarte, J., and Sun-Mack, S.: Observations of the boundary layer, cloud, and aerosol variability in the southeast Pacific near-coastal marine stratocumulus during VOCALS-REx, Atmos. Chem. Phys., 11, 9943-9959, https://doi.org/10.5194/acp-11-9943-2011, 2011. 